Faculdade de Zootecnia e Engenharia de Al iment os

\title{
Estudo da Columnariose de quatro espécies de peixes tropicais: Isolamento e Caracterização de Flavobacterium columnare
}

\section{Fabiana Pilarski}

Dissertação de Mestrado depositada na Seção de Pós-Graduação da Faculdade de Zootecnia e Engenharia de Alimentos da USP em 27 de março de 2002, como parte dos requisitos para a obtenção do Título de Mestre em Zootecnia, na área de Concentração: Qualidade e Produtividade Animal.

Orientador: Prof.Dr. Antonio Joaquim Rossini 
"Compreender e descobrir, ou reinventar através da redescoberta". É preciso atender a essas condições se quisermos formar indivíduos que, no futuro, sejam capazes de produção e criatividade, e não simplesmente de repetição". 
"Mais do que conhecimentos,

o que faz o verdadeiro mestre é o entusiasmo e a dedicação".

Ao Prof. Dr. Antonio Joaquim Rossini

A você que, possuindo sabedoria soube transmitir seus conhecimentos com amor

Meu muito obrigado

A você que soube suprir suas limitações e doou-se por inteiro a uma causa, aceitando a posição de aprendiz, caminhando ao meu lado e sendo meu maior incentivador

O meu eterno reconhecimento

A você que soube transpor as barreiras professor/aluno demonstrando confiança, carinho e respeito durante todo o período de convivência, se tornando um grande amigo e acima de tudo um exemplo de profissional digno de todo o respeito e admiração

A minha eterna gratidão. 
As eternas amigas

(Alessandra, Quarto 6 e Angélica)

"Todas nós tomamos diferentes trilhas na vida, mas não importa aonde vamos, aproveitamos um pouco de cada uma delas em toda parte e nos tornamos especiais na vida uma das outras"

- Tim Mcgrew - 


\section{Agradecimento Especial}

Aos meus pais Émerson e Inês e as minhas irmãs Emmanuelle e Elisa

Por todo o amor que demonstraram, encurtando a distância, permitindo-me transpor os abismos, os medos e as dúvidas. Dando-me ânimo e coragem quando precisei Obrigada por serem meu exemplo de vida, por me amarem e por acreditarem em mim. - A vocês dedico este trabalho - 
“O poder pode ser alcançado por meio do conhecimento; mas só o amor nos leva à perfeição." - Tagore -

\section{À Alexsandro Zidko}

Por sua constante demonstração de carinho, amor, compreensão, incentivo e paciência. Por suas sábias palavras que sortiram grandes efeitos em minha vida. Obrigada por sua presença em todos os momentos, por seu apoio e motivação. 


\section{Agradecimentos}

À Faculdade de Zootecnia e Engenharia de Alimentos da Universidade de São Paulo - Campus de Pirassununga, com deferência especial a todos os professores do curso de pós-graduação em zootecnia, pelos ensinamentos e oportunidade de realização deste curso.

Ao Centro Nacional de Pesquisa de Peixes Tropicais (CEPTA/IBAMA) pela infra-estrutura e materiais oferecidos, e pela valiosa colaboração na condução do experimento à campo bem como acervo bibliográfico.

À Coordenadoria de Aperfeiçoamento de Pessoal de Nível Superior CAPES- pela concessão da bolsa de estudos.

Ao Presidente da Comissão de pós-graduação da Faculdade de Zootecnia e Engenharia de Alimentos (FZEA/USP), Prof. Dr. Raul Franzolin Neto pelo apoio e constante colaboração.

Ao Dr. Paulo Sérgio Ceccarelli, grande amigo e exemplo de pesquisador, pela dinâmica inteligência, humildade, disponibilidade, apoio e incentivo. Por sua grande contribuição em minha formação profissional, tornando-se meu exemplo de profissional.

Ao Prof. Dr. Antonio Augusto Mendes Maia pela grande amizade, companheirismo, incentivo e colaboração durante todo o mestrado.

Ao Prof. Dr. Sérgio Araújo Antunes pela amizade, incentivo, atenção e grande contribuição na formação profissional.

Ao Prof. Dr. Rogério Lacaz Ruiz pela convivência, amizade, disponibilidade oferecida, inteligência e pela capacidade de me fazer questionar.

A equipe do Laboratório de Saúde Animal, em especial à Alessandra P. Neves e a sua família (Élder e Mauro) pela amizade, companheirismo, apoio e por me acolherem como membro da família nas horas mais alegres e pela presença nos momentos mais difíceis, e a Killarney e Márcia Gilli pela amizade, descontração, apoio e estímulo. 
Às grandes amigas Silvana M. Piccoli Pugine e Márcia R. M. da Silva Gilli pela constante colaboração, amizade, carinho e auxílio durante toda a fase do mestrado.

Aos funcionários da biblioteca da FZEA por realizarem seu trabalho de maneira tão correta, Bernadete Ap. B. Mehler, Maria O. Andrade Teixeira, Mariza E. P. Rodrigues, Patrícia F. Vick e em especial a Marcelo Roberto Dozena por toda atenção, auxílio e competência durante todo o período de mestrado.

As Funcionárias do Departamento de Ciências Básicas, Rosângela e Soraya pelo auxílio e atenção dispensadas e aos funcionários China e Toninho, pela disponibilidade e auxílio durante a condução do experimento.

As Funcionárias do Departamento de Zootecnia Érica e Estela, pela atenção, amizade e disponibilidade.

As Funcionárias da Sessão de pós-graduação em zootecnia Gláucia e Clélia por todo o auxílio, atenção e empenho na realização de suas tarefas.

A todos os pesquisadores do CEPTA/IBAMA que contribuíram para minha formação profissional, especialmente Leonardo B. Figueira, José Sávio Colares de Melo, Sérgio Moreira Ramos, Roseli Ormanezi Ramos, Rita de Cássia G.A. Rocha, Cláudio Bock, Alcinda e Luiz Alberto Gaspar (Gordo).

Aos meus grandes amigos e família Angélica Rosa Ribeiro e Donizete A. Ribeiro pelo acolhida, apoio, incentivo, carinho, amizade e grande colaboração para minha formação profisssional.

Aos alunos Juliane Gaiotto, Tatiana, Maurício (Geléia), Rodrigo (Buda) e Tiago, pela amizade, incentivo e busca de conhecimentos.

À Carina Stakoski, amiga de muitos anos, pelas horas de conversa, apoio, incentivo e carinho sem medidas.

As minhas e companheiras de "moradia" e grandes amigas Amanda A. Hayashi e Angélica S. C. Pereira, pelo carinho, amizade, compreensão e por me ensinarem a ser uma família longe de casa.

As minhas queridas amigas do quarto 6, Denise Ablas, Tatiana Reis, Kathery Brennecke, Rosane e Márcia Freiria pela grande amizade, incentivo, carinho, presença constante em minha vida e companheiras para todas as horas. 
As minhas amigas Cecília Lamontagna, Mônica Mazalli e Daniely Salvador que perto ou distantes me apoiaram e contribuíram muito com sua valiosa amizade, nunca me deixando esquecer que as pessoas que amamos não precisam estar em nossa companhia para serem lembradas.

Aos amigos de pós-graduação, Maurício Virmond, William Koury Filho, Gustavo Braga, Élson (Bentinho), Nívia, Juliana, Marcinha, Roberta, Yahn, Saulo e Adriana que fizeram este período de mestrado muito agradável e motivo de muitas recordações, especialmente a Ione (Japinha) e Márcia Saladini, por se tornarem pessoas especiais em minha vida e aos amigos mais novos (porém tão amigos quanto os outros) Maurício Peternelli, José Henrique (Gaúcho), Éder, Farah, Kelly, Luciane, Verônica e Weber pela amizade, momentos de descontração, pelas conversas e saudável convivência.

Para não citar todos os outros nomes agradeço a todos os colegas de pósgraduação pela convivência, não esquecendo a importância de ter conhecido novas pessoas que de alguma maneira tiveram importância para mim.

A todos que contribuíram com cultura e talento através de seus livros e publicações, possibilitando o surgimento de idéias e estratégias.

Se por ventura alguém foi esquecido, não o foi propositadamente.

Meu agradecimento especial a Deus, por me permitir o dom da vida e a conclusão desta dissertação, pois atribuir tantas vitórias ao acaso ou somente ao meu esforço seria impossível. 


\section{SUMÁRIO}

pág.

LISTA DE SÍMBOLOS E ABREVIATURAS ….........................................

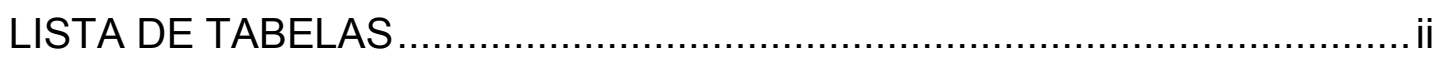

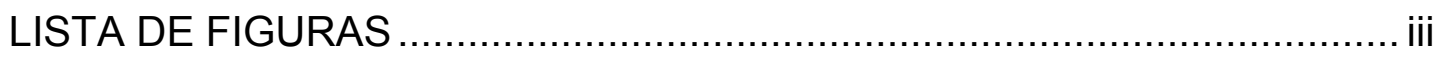

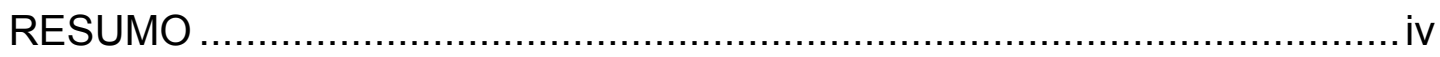

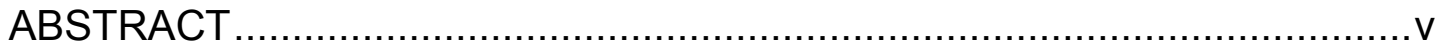

1. INTRODUÇÃO .............................................................................. 1

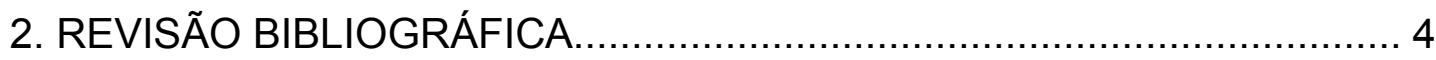

2.1 Taxonomia do agente etiológico da columnariose .......................... 4

2.2 Fatores que afetam a virulência de Flavobacterium columnare ............ 9

2.3 Fatores que contribuem para a ocorrência de Columnariose ............. 13

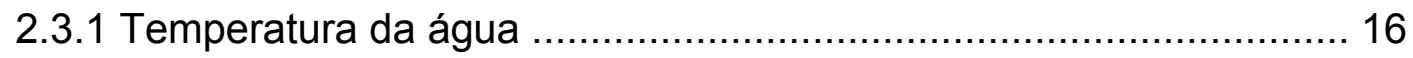

2.4 Sinais Clínicos da Doença ...................................................... 19

2.5 Características da bactéria Flavobacterium columnare .................... 21

2.6 Composição de meios de cultura artificiais utilizados para o isolamento

de Flavobacterium columnare ............................................... 23

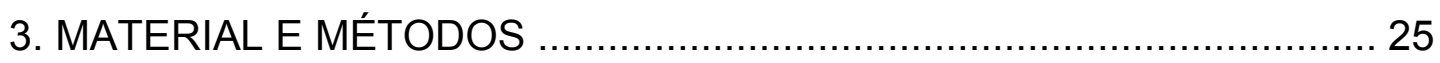

3.1 Desenvolvimento do Experimento ......................................... 25

3.2 Coleta dos materiais ................................................... 27

3.3 Meios de cultura utilizados para o isolamento e caracterização do

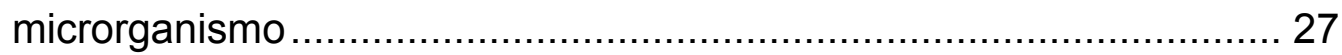

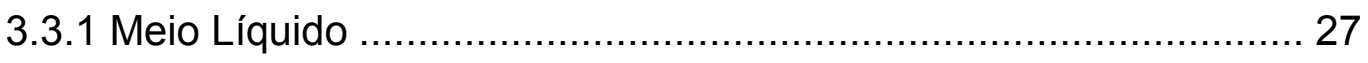

3.3.2 Preparo do infuso de carne ............................................. 28

3.3.3 Composição do Meio Líquido para o isolamento de Flavobacterium sp. 28 
3.3.4 Preparo do meio sólido para o desenvolvimento de colônias de Flavobacterium.

3.3.5 Preparo da água peptonada para diluições do material coletado e Provas Bioquímicas ................................................................ 29

3.3.6 Preparo do meio para a prova da DNase ................................ 30

3.3.7 Preparo do meio para a prova da Hidrólise do Amido .................. 30

3.3.8 Preparo do meio para a prova da Hidrólise da Gelatina ............... 30

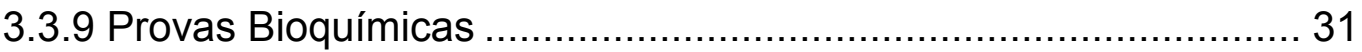

3.3.10 Outras Provas Bioquímicas...................................................... 31

3.3.10.1 Presença de Pigmento de Flexirrubina ............................... 31

3.3.10.2 Prova da Absorção do Vermelho Congo .............................. 31

3.3.10.3 Hidrólise da Caseína....................................................... 31

3.3.10.4 Redução do Nitrato ……………................................... 32

3.3.11 Técnicas de Coloração ……………………..................... 32

3.3.12 Observação da Motilidade ................................................ 32

3.4 Processamento Bacteriológico das amostras .................................. 32

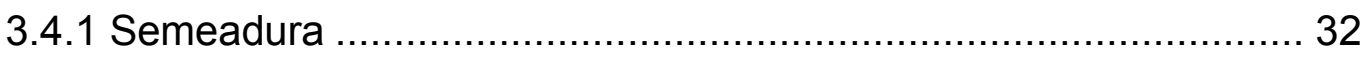

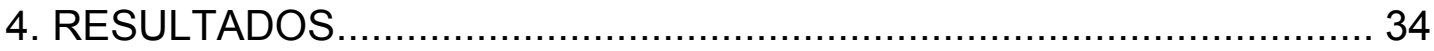

4.1 Isolamento de Cepas de Flavobacterium sp. dos peixes .................... 34

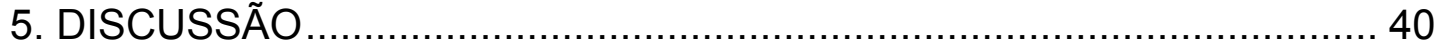

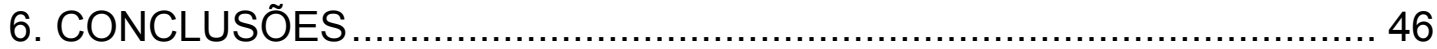

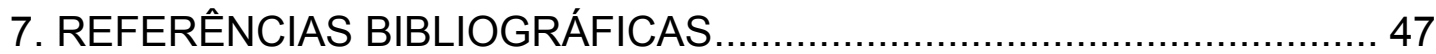




\section{LISTA DE SÍMBOLOS E ABREVIATURAS}

$\begin{array}{ll}{ }^{\circ} \mathrm{C} & \text { Graus Celsius } \\ \text { CEPTA } & \text { Centro Nacional de Pesquisa de Peixes Tropicais } \\ \text { DNA } & \text { Ácido Desoxirribonucléico } \\ \text { EUA } & \text { Estados Unidos } \\ \text { F. columnare } & \text { Flavobacterium columnare } \\ \text { FZEA } & \text { Faculdade de Zootecnia e Engenharia de Alimentos } \\ \text { Gliding } & \text { Deslizamento } \\ \text { Gram } & \text { Técnica de Coloração } \\ \mathrm{H}_{2} \mathrm{~S} & \text { Ácido Sulfídrico } \\ \mathrm{KOH} & \text { Hidróxido de Potássio } \\ \mathrm{K} 2 & \text { Brycon orbignyanus } \\ \mathrm{K} 3 & \text { Piaractus mesopotamicus } \\ \mathrm{K} 4 & \text { Colossoma macropomum } \\ \mathrm{K} 5 & \text { Hypostomus plecostomus } \\ \mathrm{mm} & \text { Milímetro } \\ \mathrm{NaOH} & \text { Hidróxido de Sódio } \\ \circledR & \text { Registrado } \\ \mu \mathrm{B} & \text { Micrograma } \\ \mu \mathrm{m} & \text { Micrometro }\end{array}$




\section{LISTA DE TABELA}

pág.

Tabela 1. Características Bioquímicas de Cepas de Flavobacterium isoladas de Peixes Tropicais 39 


\section{LISTA DE FIGURAS}

pág.

Figura 1. Exemplar de pacu - Piaractus mesopotamicus (CEPTA-

IBAMA) apresentando lesões na região dorsal, nadadeira caudal e cabeça

Figura 2. Exemplar de piracanjuba - Brycon orbignyanus (CEPTAIBAMA) apresentando lesões na região dorsal e cabeça

Figura 3. Esfregaço de raspado das áreas lesadas, coradas pelo azul de metileno a $0,5 \%$ (aumento de 1000X)

Figura 4. Esfregaço de raspado das áreas lesadas coradas pelo método de Gram (aumento de 1000X)

Figura 5. Esfregaço de cultura em meio líquido corado pelo método de Gram (aumento de 1000X)

Figura 6. Gota pendente da cultura em meio líquido (aumento de 1000X)

Figura 7. Colônia da espécie Brycon orbignyanus (piracanjuba)

observada ao aumento de $45 \mathrm{X}$

Figura 8. Colônia cinza-amarelada (aumento de 45X) da espécie Piaractus mesopotamicus (pacu)

Figura 9. Colônia cinza-amarelada (aumento de 45X) da espécie Hypostomus plecostomus (cascudo) .

Figura 10. Colônia cinza-amarelada (aumento de $45 \mathrm{X}$ ) da espécie Colossoma macropomum (tambaqui) 


\section{RESUMO}

Piracanjubas (Brycon orbignyanus), Pacus (Piaractus mesopotamicus), Tambaquis (Colossoma macropomum) e Cascudos (Hypostomus plecostomus) oriundos de criatórios do CEPTA/IBAMA atendidos pelo Laboratório de Sanidade de Peixes, foram diagnosticados como acometidos clinicamente de columnariose através de lesões características na região dorsal, caudal e brânquias dos peixes. Através de raspado das lesões e montagem a fresco em lâmina de microscopia, evidenciou-se a presença de bacilos típicos de Flavobacterium columnare (Flexibacter columnaris). Esfregaços corados com azul de metileno evidenciaram bacilos finos, arranjados em forma de colunas corados em azul. Das áreas lesadas, foi coletado através de swab estéril material para o isolamento microbiológico em meios de cultura artificiais (líquido e sólido) próprios para o estudo de Flavobacterium sp. (segundo Carlson \& Pacha, 1968). No meio líquido houve o desenvolvimento de microrganismos que, observados em gota pendente apresentaram a forma de bacilos finos, longos, móveis por deslizamento. Através da coloração de Gram apresentaram morfologia de bacilos finos, gram negativos, agrupados em colunas. $O$ plaqueamento em meio sólido desenvolveu colônias pequenas, cinza-amareladas, com bordo em forma de raiz. Foi realizada a caracterização bioquímica das amostras. Deste modo caracterizamos as quatro cepas isoladas como sendo do gênero Flavobacterium columnare.

Palavras-chaves: Caracterização Flavobacterium columnare, Isolamento/ Flavobacterium columnare, Caracterização Bioquímica/Peixes Tropicais. 


\section{ABSTRACT}

Four Flavobacterium columnare strains were isolated from piracanjubas (Brycon orbignyanus), pacus (Piaractus mesopotamicus), tambaquis (Colossoma macropomum) and cascudos (Hypostomus plecostomus), showing disease signs in the back, caudal fin and gills. The fish were obtained from different ponds at the National Center of Researches of Tropical Fish (CEPTA/IBAMA - Brazil). Samples for culture were obtained by skin scrapes of moribund fishes and was detected by wet mount using phase contrast microscope for the presence of Flavobacterium columnare. Sterile cotton swabs from the skin and gills were taken and streaked onto artificial culture medium (broth and agar) which is used for the isolation of Flavobacterium columnare. The bacterial cells of all strains in the broth cultures were gram negative, long, filamentous, exhibiting flexing movements (gliding motility) and gathered into 'columns'. Strains in the agar produced yellow-gray colonies, rather small, flat and had rhizoid edges. Biochemical characterization proved that the isolated strains could be classified as Flavobacterium columnare.

Key words: Flavobacterium columnare, isolated/ Flavobacterium columnare, Biochemical characterization/Tropical Fish. 


\section{INTRODUÇÃO}

A piscicultura é um tipo de exploração animal que vem se tornando cada vez mais importante como fonte de proteínas para o consumo humano (Chammas, 1997).

O Brasil é considerado um país com grande potencial para a piscicultura por possuir vasto território, ótimas condições climáticas e grande diversidade de peixes, altamente favoráveis aos diferentes sistemas de criação (Mesquita, 1996).

A prática de criações intensivas na piscicultura está associada a um aumento no número de enfermidades que acometem peixes, dentre elas a columnariose, que é um sério problema de saúde animal nos diferentes sistemas de produção, devido às elevadas taxas de mortalidade que provoca, fazendo com que muitos piscicultores desistam dessa atividade (Georgiadis et al., 2001).

O agente etiológico da columnariose é a bactéria Flavobacterium columnare, descrita pela primeira vez por Davis (1923), como Bacillus columnaris. Ordal \& Rucker (1944) identificaram o agente da columnariose como pertencente ao gênero Chondrococcus, espécie columnaris. 
Bernardet \& Grimont (1989), através do estudo bioquímico e molecular da bactéria, determinaram como correto o termo Flexibacter columnaris. Recentemente, Bernardet et al. (1996) sugeriram a transferência para o gênero Flavobacterium, denominando-a Flavobacterium columnare.

Clinicamente os peixes acometidos pela doença apresentam lesões limitadas à região da cabeça, dorso, brânquias e nadadeiras, caracterizadas por manchas acinzentadas e brilhantes, que podem ser rodeadas por zona avermelhada, e que nas brânquias chegam à necrose do tecido, causando a morte rápida do peixe (Davis, 1947; Pacha \& Ordal, 1970; Farkas \& Olah, 1986; Martins, 1997).

Desde a década de 80 a columnariose tem tido substancial impacto na piscicultura, tornando-se uma doença de ocorrência universal (Anderson \& Conroy, 1969; Liewes et al., 1982; Austin \& Austin, 1989; Decostere et al., 1998) e um dos maiores obstáculos para o futuro crescimento da aquicultura mundial, devido às erosões cutâneas que provoca, e pelo tratamento que é oneroso (Soltani et al.; 1996).

A columnariose além de ser um grave problema de sanidade, diminui a produção, devido à elevada e rápida mortalidade dos alevinos, chegando até mesmo a dizimar cardumes (Ceccarelli et al., 1990). Apesar deste fato, poucos são os trabalhos existentes na literatura brasileira que abordam a columnariose de peixes tropicais. O estudo dessa bacteriose torna-se de importância uma vez que o controle e a profilaxia da doença decorrem do conhecimento do agente etiológico. 
Assim, o presente trabalho teve por objetivo:

- Isolar das espécies de peixes tropicais, clinicamente diagnosticadas como acometidas de columnariose, o agente microbiológico através da morfologia, propriedades culturais e comportamento bioquímico. 


\section{REVISÃO BIBLIOGRÁFICA}

\subsection{Taxonomia do agente etiológico da columnariose}

Dentre as enfermidades causadas por bactérias em peixes, têm sido descritas espécies patógenas em uma variedade de grupos bacterianos, sendo que os bacilos gram negativos representam a porcentagem mais elevada (Barja \& Estevez Toranzo, 1988).

As bactérias gram negativas englobam os gênero Cytophaga, Flavobacterium, Myxobacterium e Sprocytophaga. O fator comum entre esses gêneros consiste na dificuldade de identificação das espécies (Austin \& Austin, 1989).

Historicamente, o interesse pelas bactérias gram negativas iniciou com a publicação de Davis (1923), que primeiramente descreveu a bactéria Flavobacterium columnare como a causa de séria mortalidade em uma grande variedade de peixes do Rio Mississipi (EUA). Esses peixes permaneceram em uma estação biológica de lowa (EUA) para observação. Davis reconheceu dois aspectos importantes da doença: ela ocorria primeiramente em peixes com algum tipo de ferimento ou que estivessem estressados e a doença era consequência da elevada temperatura da água. Embora o pesquisador tivesse fracassado na tentativa de cultivar a bactéria observada nas lesões dos peixes, desenvolveu evidências presuntivas do relacionamento desta bactéria com a doença, descrevendo-a muito bem. 
Davis verificou que ao colocar o material das lesões sob uma gota de água, movimentos característicos ocorriam, formando pequenas massas bacterianas em forma de colunas. Esta formação foi considerada característica da espécie, sendo proposto o nome de Bacillus columnaris. A bactéria por ele descoberta foi considerada uma myxobactéria, por ser móvel, possuir tamanho e forma característica do gênero, incluindo a formação de massas de células como colunas.

Nigrelli (1943) notificou a ocorrência de uma doença semelhante à descrita por Davis em bagres do canal (Ictalurus punctatus) em aquários de Nova lorque, com elevadas taxas de mortalidade.

Ordal \& Rucker (1944) identificaram em Washington (EUA) uma epizootia em salmões (Salmo salar) e chegaram à conclusão que esta era semelhante, senão idêntica, à enfermidade bacteriana que acometia peixes de águas quentes descrita por Davis (1923).

A busca da origem primária da bactéria responsável pelo grande número de mortalidades em salmonídeos permitiu a Ordal \& Rucker (1944) o isolamento da bactéria em cultura pura de lesões da superfície corporal e órgãos internos de peixes doentes. Essa bactéria correspondia ao Bacillus columnaris de Davis (1923) em tamanho, forma, flexibilidade e, particularmente, no movimento característico de deslizamento (gliding), incluindo a formação de colunas.

Os pesquisadores acima descritos acataram a descrição da espécie columnaris proposta por Davis, porém modificaram o gênero para Chondrococcus, devido à observação de culturas com estrutura oval e 
espiral, denominadas de microcistos, as quais não foram evidenciadas por Davis. Foram realizadas infecções experimentais com essa bactéria e a doença referida como columnariose foi reproduzida em salmões saudáveis. Culturas puras do agente etiológico foram desenvolvidas para infecções experimentais com outras espécies de peixes.

Fish \& Rucker (1945) identificaram a ocorrência de columnariose em peixes de águas frias.

Garnjobst (1945) isolou uma bactéria de peixes infectados no laboratório de Leetown na Virgínia (EUA), considerando-a idêntica a Bacillus columnaris (Davis, 1923). Esta bactéria também assemelhava-se muito à Chondrococcus columnaris (Ordal e Rucker, 1944) na morfologia e nas características de movimento, porém não produzia microcistos e corpos frutificadores, sendo designada como Cytophaga columnaris.

Borg (1948) considerou a questão taxonômica da bactéria isolada de peixes com columnariose e concordou com Ordal \& Rucker (1944) quanto à denominação de Chondrococcus columnaris. A respeito do microorganismo isolado por Garnjobst (1945) sugeriu-se que cepas não produtoras de corpos frutificadores poderiam existir na natureza e que a bactéria denominada como Cytophaga columnaris poderia ser um exemplo dessa cepa.

Segundo Rucker et al. (1953), algumas cepas produziam colônias típicas em meio de cultura sólido, com diferentes variações dos isolamentos originais, pois algumas dessas culturas não produziam corpos frutificadores. Aparentemente a produção de corpos frutificadores era um 
processo complexo e mudanças degenerativas poderiam ocorrer nas culturas quando estas se desenvolviam em meios artificiais de cultura, permitindo a seleção de cepas que seriam incapazes de produzir ou maturar corpos frutificadores.

Davis (1946) observou que a bactéria Cytophaga columnaris foi responsável por inúmeras infecções em trutas (Salvelinus fontinalis), em tanques de criações nos Estados Unidos, resultando em alta mortalidade, tanto em alevinos como em peixes adultos.

A bactéria até o momento referida como Cytophaga columnaris foi considerada por unanimidade pelos pesquisadores como um importante patógeno, tanto em tanques de criações como em rios, lagos, córregos e represas. Tornou-se muito difícil, senão impossível, quantificar o número de mortalidades por columnariose que ocorriam em ambientes naturais devido a fatores como predação dos peixes, sedimentação e decomposição. Assim, eram relatados somente casos de columnariose ocorridos em tanques de criações (Rucker \& Ordal, 1954).

Desde então, a columnariose tem sido reconhecida como um patógeno de distribuição universal, em peixes de criação e em peixes selvagens (Austin \& Austin, 1989).

Em 1949 um grande número de mortalidade por bacteriose foi constatado em Oregon (EUA), devido a um surto de columnariose em pisciculturas locais provocando grande prejuízo econômico (Davis, 1949). Davis relatou que esta enfermidade se alastrava por vários Estados e em 
seus relatos nenhuma menção foi feita à questão da produção de corpos frutificadores.

Com mais deliberação, após vários anos de estudo à respeito da taxonomia dessa bactéria, Leadbetter (1974) transferiu o microorganismo do gênero Cytophaga para o gênero Flexibacter. A partir desta data, a bactéria passou a ser denominada de Flexibacter columnaris.

O microorganismo permaneceu nesse gênero até o ano de 1989, quando Bernardet \& Grimont, caracterizando bioquimicamente a bactéria e estudando os componentes de seu DNA, novamente modificaram sua nomenclatura, designando-a como pertencente ao gênero Flavobacterium.

A partir de 1994, o gênero Flavobacterium foi reorganizado e dividido em duas seções, segundo componentes do seu DNA. A seção um continha Flavobacterium sp. caracterizada pela quantidade de guanina + citosina referente a $30-42 \%$ mol. A seção dois apresentava Flavobacterium sp. com 63-70\% mol de guanina + citosina (Jooste \& Hugo, 1999).

Bernardet et al. (1996), através de estudos genômicos (DNArRNA) da bactéria identificaram similaridades da espécie columnaris com o gênero Flavobacterium, incluindo a motilidade por deslizamento, conteúdo do DNA entre $32-37 \%$ mol, e a produção de pigmentos. Assim, os pesquisadores propuseram uma nova descrição do gênero Flavobacterium e uma nova classificação, passando de sete espécies reconhecidas para dez, incluindo neste gênero a bactéria Flavobacterium columnare. O nome Flavobacterium columnare tornou-se reconhecido neste mesmo ano através 
de sua publicação no Jornal Internacional de Sistemática Bacteriana (Newton et al., 1997).

Atualmente, o gênero Flavobacterium engloba as seguintes espécies: Flavobacterium aquatile, Flavobacterium branchiophilum, Flavobacterium columnare, Flavobacterium flevense, Flavobacterium hydatis, Flavobacterium johnsoniae, Flavobacterium pectinovorum, Flavobacterium psychrophilum, Flavobacterium saccharophilum e Flavobacterium succinicans. Estes microorganismos estão amplamente distribuídos no solo e em ambientes aquáticos, e a maioria das espécies é patogênica para os peixes de água doce (Schreckenberger, 1998).

\subsection{Fatores que afetam a virulência de Flavobacterium columnare}

Para causar infecção em um organismo, a maioria dos patógenos deve ser capaz de penetrar no hospedeiro, conseguir multiplicarse nos tecidos do hospedeiro, resistir, não estimulando as defesas do hospedeiro, e, por último, provocar danos a este hospedeiro. Quanto mais eficazmente forem realizadas cada uma destas ações, mais virulento será o patógeno (Torroella, 1988).

São poucos os patógenos que produzem enfermidades sem penetrar em seu hospedeiro. Entre eles encontram-se os ectoparasitos e as bactérias, que se alojam na parte externa das mucosas (brânquias, pele) e produzem toxinas. Portanto, o primeiro requisito de virulência nos patógenos é a sua capacidade de penetrar no corpo do hospedeiro (McCarthy, 1983). 
Rucker et al. (1954) iniciaram pesquisas sobre a diferença de virulência existente entre as cepas de Flavobacterium columnare, notificando que as cepas poderiam ter virulência elevada ou reduzida. As cepas de baixa virulência provocavam extensos prejuízos à superfície corporal dos peixes, tendo como conseqüência um grande número de mortalidade em tanques de criações ou em ambientes naturais, quando a temperatura da água mantinha-se elevada. Já as cepas de virulência elevada, quando testadas em infecções experimentais, produziam uma doença assintomática fatal, que resultava na morte fulminante dos peixes, com taxas de mortalidade chegando a $100 \%$ no período de 12 a 24 horas. Também foi observada a septicemia provocada por essas cepas aos peixes.

Provavelmente cepas do microorganismo com virulência elevada possuíam um componente lipídico em sua membrana celular, e este componente encontrava-se ausente ou quantitativamente em menor abundância em cepas de baixa virulência (Dyar \& Ordal, 1946). Após o cultivo de Flavobacterium columnare em meios artificiais de cultura por um período de dezoito meses, a cultura foi testada e concluíram que sua patogenicidade havia sido perdida e o componente lipídico não se encontrava mais presente na membrana celular. Mesmo sabendo que a patogenicidade das cepas de virulência elevada seja perdida em repiques em meio de cultura artificiais, ainda não é possível diferenciar cepas de virulência elevada de cepas de virulência reduzida através de diluições das culturas (Rucker \& Ordal, 1954). 
Foi relatada ainda a possibilidade de que cepas de virulência elevada fossem o resultado de recombinações sexuais no complexo ciclo de vida do microorganismo (Dyar \& Ordal, 1946).

Apesar desses grandes avanços alcançados, há muito pouca informação acerca dos fatores determinantes na fixação e seu papel na patogenicidade de Flavobacterium columnare (Toranzo \& Barja, 1993).

Contrastando com a maioria dos patógenos de peixes, em infecções artificiais as cepas com virulência elevada da bactéria, foi demonstrado que sua efetividade é maior pela simples exposição à bactéria do que por inoculações (Pacha \& Ordal, 1970).

Os peixes em condições normais possuem o corpo recoberto por uma capa de muco, na qual estão presentes moléculas com capacidade antimicrobiana e, em alguns casos, por microorganismos comensais que competem com os patógenos. Além do mais, as mucosas estão habitualmente sujeitas a um forte movimento de fluídos, por isso a capacidade de adesão é especialmente necessária para os patógenos que devem penetrar no organismo e resistir à contínua corrente de água sob os filamentos branquiais (Torrella, 1988).

Peixes mantidos em águas lênticas demonstraram ser mais suscetíveis à columnariose, quando comparados a peixes mantidos em águas lóticas, sugerindo que águas paradas favorecem a fixação de Flavobacterium columnare à superfície corporal dos peixes (Decostere et al., 1999b). 
Decostere et al. (1999a) investigaram a habilidade de fixação nas brânquias de Poecilia sphenops de cepas de virulência elevada (AJS 1) e reduzida (AJS 4) de Flavobacterium columnare. Exames bacteriológicos comprovaram que o número de cepas de $F$. columnare associada às brânquias dos peixes foi maior para as cepas AJS 1 do que para cepas AJS 4. Esta associação com as células do hospedeiro foi considerada o primeiro passo no estabelecimento da bactéria à superfície corporal do peixe e, por isso, um importante fator de virulência. Porém, os antígenos envolvidos na fixação de cepas de elevada virulência não foram identificados. Os possíveis implicados foram a cápsula, a fímbria ou outros apêndices externos da membrana. Nesse trabalho também foi observada a presença de cepas de alta virulência nos órgãos internos dos peixes infectados experimentalmente, indicando que essas cepas foram capazes de penetrar na corrente sangüínea dos peixes. Entretanto, não ficou esclarecido se existiu correlação entre a capacidade de adesão da bactéria e a habilidade de provocar septicemia.

Embora muitos pesquisadores tenham notificado a presença de septicemia em infecções experimentais (Hawke \& Thune, 1992; Koski et al., 1993), a columnariose primeiramente provoca a enfermidade nas brânquias e na superfície corporal dos peixes (Decostere et al., 1999b). Os mesmos autores realizaram outra pesquisa a respeito da influência da qualidade de água e da temperatura na adesão de cepas de Flavobacterium columnare de alta e baixa virulência às brânquias de peixes infectados experimentalmente e comprovaram que as cepas de virulência elevada possuíam maior 
habilidade de adesão do que cepas de baixa virulência, e esta capacidade de adesão às brânquias foi influenciada pela composição iônica da água, isto é, a adesão foi maior quando foram adicionados ions de magnésio e cálcio na água. O mesmo ocorreu com a temperatura da água, onde cepas de virulência elevada foram capazes de atacar o epitélio branquial quando a temperatura da água permaneceu elevada.

Hanson \& Grizzle (1985) também concluíram que elevados níveis de nitrato $(5 \mathrm{mg} / \mathrm{l})$ e a presença de matéria orgânica aumentavam a adesão de cepas de virulência elevada de Flavobacterium columnare e induziam a predisposição dos peixes a columnariose.

Assim, os pesquisadores concluíram que a qualidade e a temperatura da água foram dois fatores importantes que influenciaram a ocorrência de columnariose nos peixes, pois facilitaram a capacidade de adesão de cepas de alta virulência aos tecidos dos peixes.

\subsection{Fatores que contribuem para a ocorrência de Columnariose}

O reservatório preciso de muitos patógenos de peixes

permanece obscuro (Austin \& Austin, 1989), entretanto, sabe-se que a ocorrência de doenças infecciosas depende de interações entre o patógeno, hospedeiro e o meio aquático (Jeney \& Jeney, 1995).

A bactéria Flavobacterium columnare é considerada oportunista, e compõe parte da microbiota normal da água, pele e brânquias dos peixes ((Barja \& Estevez Toranzo, 1988). Porém, sob condições 
desfavoráveis aos peixes, tais como, uma repentina mudança de temperatura, diminuição da taxa de oxigênio dissolvido, elevada densidade populacional de peixes, contaminação por outras bactérias, meio eutrófico ou danos causados à superfície corporal dos peixes, a bactéria torna-se um patógeno em potencial, desencadeando epizootias (Wakabayashi \& Egusa, 1972; Wakabayashi, 1991; Zhao et al., 1997).

Essas condições desfavoráveis são identificadas como estressantes aos peixes, e são capazes de alterar sua função imune, quando glicocorticóides são secretados em resposta ao estresse, suprimindo a função dos linfócitos, macrófagos e neutrófilos, aumentando a susceptibilidade dos peixes a doenças, principalmente à columnariose (Jeney et al., 1997).

Outra condição que contribui para o surgimento da columnariose é a competição bacteriana (Wakabayashi \& Egusa, 1972). A bactéria Flavobacterium columnare está sujeita a competir com outras bactérias no ambiente aquático ou na superfície corporal dos peixes, fatores estes que limitam sua infectividade ou sobrevivência (Chowdhury \& Wakabayashi, 1989a).

O que muito tem sido discutido pelos pesquisadores é se a bactéria Flavobacterium columnare pode iniciar uma infeção ou se é necessária uma infeção preexistente para ocorrer a manifestação da columnariose.

Bullock (1968) sugeriu que o papel da Flavobacterium columnare era de invasor secundário. Ele observou a evolução da 
columnariose em trutas-arco-íris (Oncorhynchus mykiss) e percebeu diferentes estágios de necrose das nadadeiras, deduzindo que o envolvimento da bactéria ocorreu após uma lesão resultante da presença de outra doença, balanço nutricional, traumatismos ou outros fatores predisponentes.

Marks et al. (1980) relataram sérias manifestações de columnariose em bagres do canal (Ictalurus punctatus) após uma infeção primária por Corynebacterium sp. O mesmo foi constatado por Kimura \& Kusuda (1983), os quais estudaram infecções por Flavobacterium columnare e descobriram que uma doença primária favorecia o crescimento e facilitava a invasão de Flavobacterium columnare no tecido epitelial dos peixes, como por exemplo uma infecção iniciada por Vibrio sp.

Chowdhury \& Wakabayashi (1989b) verificaram que Aeromonas hydrophila, Citrobacter freundii e Vibrio sp. também presentes na superfície corporal dos peixes, competiam com Flavobacterium columnare, diminuindo sua sobrevivência e infectividade. Os pesquisadores observaram que a competição bacteriana era um dos fatores inibitórios à sobrevivência e infectividade de Flavobacterium columnare, pois sua proliferação somente ocorria após o seu estabelecimento na superfície corporal dos peixes e, para que isso pudesse acontecer, a competição bacteriana deveria estar ausente.

Dentre todas essas condições estressantes aos peixes, a que merece maior destaque é a temperatura, pelo fato da Flavobacterium columnare ocorrer sob uma ampla extensão de temperatura (Aranishi, 2000) e sua patogenicidade ser aumentada com a elevação da mesma, com taxas 
de mortalidade de 10 a $100 \%$ dependendo da temperatura da água (Bernardet, 1989).

\subsubsection{Temperatura da água}

A temperatura da água exerce uma grande influência sobre todas as funções fisiológicas dos peixes, incluindo a resposta imune. As reações às mudanças repentinas de temperatura dependem das espécies de peixes, porém pode-se afirmar que baixas temperaturas podem suprimir parte da resposta imune (Avtalion et al., 1973). Por outro lado, temperaturas elevadas podem provocar uma reação de estresse, tendo como consequência a imunosupressão (Torrella, 1988).

Deve-se salientar também as respostas diferenciais dos patógenos à temperatura da água. As bactérias patogênicas oportunistas podem, com um rápido aumento da temperatura, multiplicar-se mais rapidamente (Griffin, 1992).

Embora as doenças bacterianas ocorram sob uma ampla faixa de temperatura, as bacterioses são aumentadas com a elevação da mesma. Há exemplos muito bem documentados sobre a interação entre a temperatura da água e o desenvolvimento de infecções (Aranishi, 2000).

Garnjobst (1945) observou que com o aumento da temperatura lesões características de Flavobacterium colmnare surgiram nos peixes, induzindo a columnariose, com taxas de mortalidade de $100 \%$. 
Rucker et al. (1954) descreveram que a columnariose poderia provocar um grande número de mortalidade em tanques de criações ou corpos d'água naturais quando a temperatura da água permanecia elevada.

Fujihara \& Nakatani (1971) estudaram os efeitos da temperatura sobre a taxa de mortalidade de trutas arco-íris (Oncorhynchus mykiss) em tanques de criação e relataram que a mortalidade estava diretamente associada ao início do verão e ao grande número de Flavobacterium columnare encontradas na água e nos peixes. Quando a temperatura da água foi superior a $15,8{ }^{\circ} \mathrm{C}$ a taxa de mortalidade entre os peixes ultrapassou $76 \%$.

Geralmente epizootias ocorrem quando a temperatura da água permanece entre $18-22{ }^{\circ} \mathrm{C}$ e raramente a doença acarreta alguma consequência com temperaturas inferiores a $15^{\circ} \mathrm{C}$ (Amend, 1970).

Para esclarecer os drásticos efeitos da temperatura da água nos níveis de mortalidade, Holt et al. (1975) realizaram um estudo sobre o efeito de diferentes temperaturas na infectividade de Flavobacterium columnare e concluíram que a temperatura foi altamente relevante. Quando a temperatura da água se estabeleceu em $9,4{ }^{\circ} \mathrm{C}$ nenhuma mortalidade foi atribuída à bactéria; com temperatura de $12,2{ }^{\circ} \mathrm{C}, 4-20 \%$ de mortalidades ocorreram e; $20,5^{\circ} \mathrm{C}$ a taxa de mortalidade chegou a $90 \%$.

Chen et al. (1982) relataram perdas por mortalidade de peixes por columnariose entre 77 e $88,3 \%$ quando a temperatura da água estava elevada. 
Já em experimentos realizados por Bernardet (1989) e Wakabayashi (1991) a taxa de mortalidade chegou a $100 \%$ quando a temperatura da água permaneceu acima de $16{ }^{\circ} \mathrm{C}$. Além do mais, a temperatura da água influencia diretamente na patogenicidade de Flavobacterium columnare, pois cepas de virulência reduzida tornam-se patogênicas quando esta permanece acima de $20{ }^{\circ} \mathrm{C}$ e cepas de virulência elevada são extremamente patogênicas a temperaturas superiores a $15^{\circ} \mathrm{C}$ (Bernardet, 1989).

$\mathrm{Na}$ condução de um experimento com bagres, Carson et al. (1993) verificaram que os surtos de columnariose ocorreram durante o período de maior estresse aos peixes, quando estes foram estocados em alta densidade. A situação foi agravada pelas condições climáticas desfavoráveis, como a elevação da temperatura da água de $27^{\circ} \mathrm{C}$ para 35 ${ }^{\circ} \mathrm{C}$.

Soltani et al. (1996) estudaram a relativa susceptibilidade de peixes a infecções por Flavobacterium columnare e chegaram à conclusão de que a temperatura ótima para a proliferação desta bactéria nos tecidos dos peixes encontrava-se entre 20 e $35^{\circ} \mathrm{C}$, e a temperatura da água mantida sob essa faixa resultava em elevadas taxas de mortalidade devido à erupção da columnariose.

Sabendo que o impacto da columnariose sobre uma população de peixes depende da temperatura da água, deduz-se a importância de métodos efetivos de controle desta enfermidade em condições tropicais, 
onde a temperatura da água permanece acima de $20{ }^{\circ} \mathrm{C}$ a maior parte do ano (Bermúdez, 1980).

\subsection{Sinais Clínicos da Doença}

Os peixes acometidos pela columnariose apresentam pontos acinzentados ou áreas amareladas de erosão, usualmente envoltas por uma zona avermelhada hiperêmica na cabeça, superfície corporal e brânquias, locais estes de progressivas necroses envolvendo a epiderme, derme e musculatura (Davis, 1923; Pacha \& Ordal, 1967; Farkas \& Olah, 1986; Bertoline \& Rohovec, 1992).

Pacha \& Ordal (1970) descreveram que a ação patogênica de Flavobacterium columnare ocorria através da liberação de potentes enzimas proteolíticas que seriam as responsáveis pelos severos processos necróticos observados em peixes com columnariose.

De acordo com Bullock et al. (1971) o progresso da columnariose era variável. Em tanques, lagos e rios com temperaturas elevadas, os peixes eram acometidos pela doença. Nesses casos eram observadas extensas áreas necrosadas da derme ou até uma septicemia. 0 pesquisador concluiu que em tais casos a morte dos peixes era ocasionada pela perda de eletrólitos e de proteínas através das lesões abertas. Nessas lesões foi observada a presença de bactérias longas e finas, exibindo movimentos flexíveis e capazes de formar colunas (Decostere et al., 1997).

Em casos de columnariose sistêmica, a morte do peixe provavelmente ocorre como resultado da liberação de toxinas bacterianas ou 
por toxinas liberadas pelo hospedeiro devido à intensa ação proteolítica da bactéria (Bullock et al., 1971).

Na superfície corporal, pequenas lesões se iniciam como áreas descoloridas, propagando-se até a base da nadadeira dorsal ou, ocasionalmente, até a base da nadadeira pélvica, promovendo a deterioração das nadadeiras. Estas áreas aumentam em tamanho e podem chegar a 3-4 cm de diâmetro, cobrindo 20-25 \% da superfície corporal dos peixes, onde a pele fica completamente corroída expondo a musculatura (Austin \& Austin, 1989)

As lesões são cobertas por um exudato amarelado onde é encontrada um grande número de Flavobacterium columnare (Jeney \& Jeney, 1995), por isso é comum a morte do peixe em 48 horas após o surgimento da descoloração na pele (Wakabayashi, 1991). Quando essas lesões ocorrem ao redor da nadadeira dorsal, a doença é denominada de "doença da sela" (Bootsma \& Clerx, 1976; Austin \& Austin, 1989; Bernardet \& Grimont, 1989; Decostere et al., 1999b).

As brânquias são atacadas de maneira própria, com destruição dos filamentos, iniciando-se na periferia das brânquias e estendendo-se da parte distal em direção à base. A proliferação de massas bacterianas no epitélio branquial provoca a hiperplasia desses filamentos, com fusão da lamela e, em casos extremos, a união dos filamentos. Estes filamentos branquiais tornam-se congestos pelo acúmulo de massas lobosas de sangue, promovendo a interrupção da troca de gases entre a água e a corrente sangüínea. A hiperplasia do epitélio branquial e a hiperprodução de 
muco absorvem o espaço inter-lamelar e limitam a absorção de oxigênio pelas brânquias, provocando a morte do peixe por asfixia (Rucker et al., 1952; Wood \& Yasutake, 1957).

Em infecções experimentais, Foscarini (1989) notou que, no período de 6-24 horas após a exposição inicial do peixe à Flavobacterium columnare, os peixes demonstraram uma acentuada hiperplasia da lamela primária e secundária. Após 48 horas a lamela secundária tornou-se congesta pelo acúmulo de massas de sangue. Em alguns peixes observouse a destruição de eritrócitos nos capilares da lamela secundária. Em casos mais graves foi observada a união completa dos filamentos branquiais.

O coração demonstra artérias coronárias congestas e alteração da performance cardíaca (redução dos batimentos cardíacos). A diminuição da freqüência cardíaca ocorre devido à condição anóxica. A bradicardia sob a redução do oxigênio pode ser uma estratégia para proteger o músculo miocárdio de uma hipoxia. Essa condição também pode ter um importante papel na promoção mais eficiente da troca gasosa entre o sangue circulante na lamela e a água (Foscarini, 1989; Bragg, 1991).

\subsection{Características da bactéria Flavobacterium columnare}

A bactéria é um bacilo gram negativo moderadamente longo, com lados paralelos suavemente irregulares e circulares ou suavemente afilados (Garnjobst, 1945). Usualmente medem de 0,3-0,6 $\mu \mathrm{m}$ de diâmetro e 1-10 $\mu \mathrm{m}$ de extensão. As células em culturas velhas podem formar corpos 
esféricos ou cocóides, incluindo também a formação de massas de células como colunas (Rucker et al., 1954).

Sua multiplicação é por divisão transversa, usualmente dentro de duas células de aproximadamente igual tamanho (Stanier, 1942). Não formam esporos e são desprovidas de flagelo. Produzem polímeros extracelulares, que deixam um vestígio de muco e servem para a motilidade por deslizamento em diferentes superfícies, sólidas ou semi-sólidas (Carlson \& Pacha, 1968).

O crescimento é aeróbio, com temperatura ótima geralmente em torno de $25-35{ }^{\circ} \mathrm{C}$ (Garnjobst, 1945). Em meio sólido o crescimento das colônias se inicia com uma coloração amarelo pálido e após o terceiro dia elas são tipicamente amareladas, variando do creme para o laranja (Schreckenberger, 1998), formam aglomerados de bactérias no meio sólido que não excedem $5,0 \mathrm{~cm}$ de diâmetro.

A morfologia da colônia pode ser de três tipos: rizóide, mucóide ou em forma de favo de mel (Song et al., 1988; Triyanto \& Wakabayashi, 1999).

Em meio líquido o crescimento é turvo e algumas vezes possui uma película que se torna amarelada de acordo com a idade da cultura. Com temperatura entre 13 e $18{ }^{\circ} \mathrm{C}$ as células permanecem na superfície inferior do tubo de cultura (Garnjobst, 1945).

A menaquinona 6 é a quinona utilizada na respiração. A bactéria não decompõe a celulose, o amido e o ágar. A composição de seu DNA varia de $29-45 \%$ de guanina+citosina (Jooste \& Hugo, 1999). A 
concentração de sal suportada pela bactéria varia de $0,3 \quad \%$ a $0,5 \%$ (Garnjobst, 1945).

Toyama et al., (1996) demonstraram que poderiam ocorrer variações genéticas intra-espécies entre cepas de Flavobacterium columnare onde as características fenotípicas da bactéria são homogêneas, com algumas exceções, como a habilidade de crescer a $37{ }^{\circ} \mathrm{C}$ e $15{ }^{\circ} \mathrm{C}$ (Bernardet, 1989), redução de nitrato (Shamsudin \& Plumb, 1996) e morfologia da colônia (Song et al., 1988).

\subsection{Composição de meios de cultura artificiais utilizados para o isolamento de Flavobacterium columnare}

Uma variedade de meios de cultura tem sido utilizada na tentativa de isolar Flavobacterium columnare, porém comparações quanto à eficácia desses meios não são freqüentes pelo fato de poucos pesquisadores em todo o mundo estudarem esse microorganismo (Jooste \& Hugo, 1999).

Ordal \& Rucker (1944) descreveram o primeiro meio para o isolamento de Flavobacterium columnare, porém Fijan (1968) observou uma discreta formação de colônias da bactéria no ágar, que foi frustrado pelo crescimento de outras bactérias presentes no meio, denotando que o meio não foi realmente seletivo.

Assim, após vários anos de estudo, Shieh (1980) formulou um

novo meio para o isolamento de Flavobacterium columnare, ao qual 
acrescentou diferentes compostos inorgânicos, relatando que esses compostos promoviam um ótimo crescimento do microorganismo.

Song et al. (1988) comprovaram a eficácia do meio de Shieh (1980), e relataram que este meio realmente promovia um melhor crescimento de Flavobacterium columnare.

Apesar de todos os conhecimentos a respeito de Flavobacterium columnare, poucos são os pesquisadores que trabalham para o isolamento desta bactéria. Portanto, no capítulo a seguir serão discutidos o material utilizado e os métodos empregados no isolamento de Flavobacterium columnare de peixes tropicais no Brasil. 


\section{MATERIAL E MÉTODOS}

\subsection{Desenvolvimento do Trabalho}

Foram selecionados 50 peixes das seguintes espécies: 13 Pacus (Piaractus mesopotamicus), 15 Tambaquis (Colossoma macropomum), 12 Piracanjubas (Brycon orbignyanus) e 10 Cascudos (Hypostomus plecostomus), clinicamente diagnosticados como acometidos de columnariose pelo setor de Sanidade de Peixes do Centro Nacional de Pesquisa de Peixes Tropicais (CEPTA/IBAMA de Pirassununga, SP) (Figuras 1 e 2)

O estudo bacteriológico foi realizado no Laboratório de Saúde Animal da FZEA-ZAB/USP, Campus de Pirassununga. 


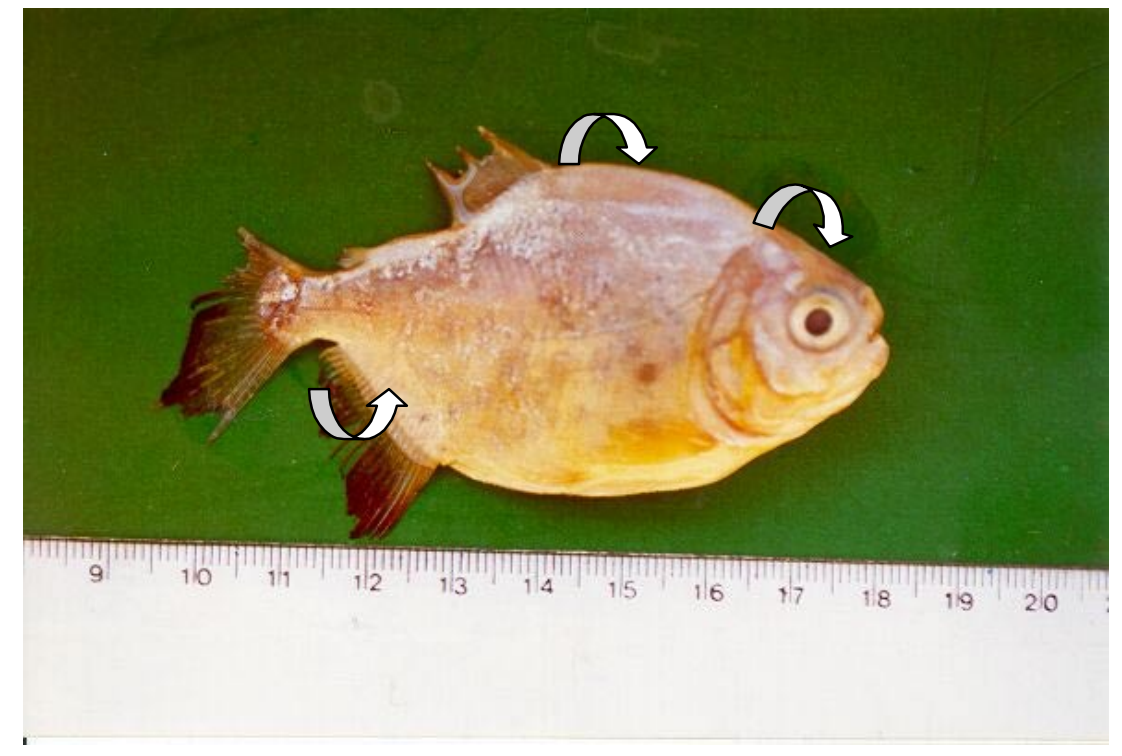

Figura 1. Exemplar de pacu Piaractus mesopotamicus (CEPTA/IBAMA), apresentando áreas descoloridas na região dorsal, nadadeira caudal e cabeça.

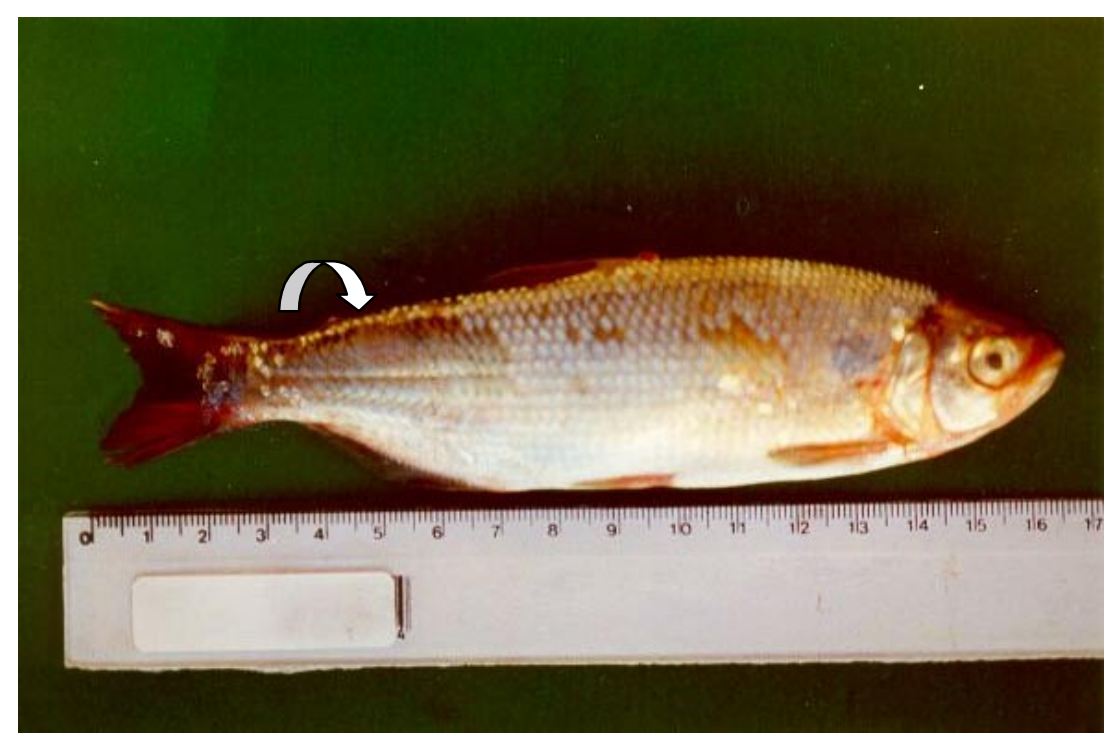

Figura 2. Exemplar de piracanjuba Brycon orbignyanus (CEPTA/IBAMA), apresentando áreas descolorias na região dorsal. 


\subsection{Coleta dos materiais}

O material de estudo foi obtido através de dois swabs estéreis, aplicados nas áreas com lesões características de columnariose (brânquias, superfície dorsal e pedúnculo caudal) dos peixes examinados; Um deles foi imediatamente semeado em meio de cultura líquido, e transportado ao laboratório e incubado em estufa bacteriológica $\left(25^{\circ} \mathrm{C}\right)$ e o outro utilizado para técnicas de coloração (azul de metileno e método de Gram).

\subsection{Meios de cultura utilizados para o isolamento e caracterização do microorganismo}

Para o isolamento do microorganismo, utilizaram-se os meios artificiais de cultura preconizados por Carlson \& Pacha (1968) com modificações por nós introduzidas, tais como substituição do extrato de carne bovina por extrato de carne de peixe, adição de peptona e cloreto de sódio e exclusão de triptona e leite.

\subsubsection{Meio Líquido}

Preparo da água de músculo esquelético não descamado de tilápia (Oreochromis niloticus) para o preparo do infuso de carne.

Músculo de peixe com escama $15 \mathrm{~g}$ Água destilada $1000 \mathrm{ml}$ 
Através de liqüidificador doméstico, o músculo esquelético não descamado foi triturado durante vinte minutos e, em seguida, fervido durante cinco minutos. Após repousar por trinta minutos para decantação, o sobrenadante foi filtrado em papel de filtro (Whatman $n^{0} 3$ ), obtendo-se um líquido claro e límpido.

A seguir ajustou-se o $\mathrm{pH}$ para 6,6 com $\mathrm{NaOH}$.

\subsubsection{Preparo do infuso de carne}

Água de músculo esquelético $300 \mathrm{ml}$

Peptona ${ }^{(1)}$ $3 \mathrm{~g}$

Cloreto de Sódio ${ }^{(2)}$ $0,02 \mathrm{~g}$

3.3.3 Composição do Meio Líquido para o isolamento de Flavobacterium sp.

Infuso de Carne $100 \mathrm{ml}$

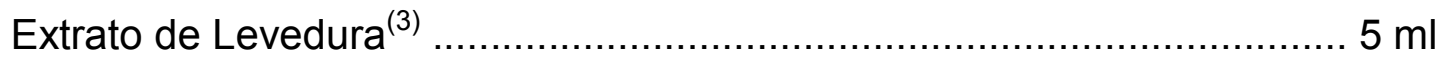

Acetato de Sódio $0,02 \mathrm{~g}$

pH ajustado para 6,8 com $\mathrm{NaOH}$.

\footnotetext{
${ }^{1}$ Bacto Peptone Difco Laboratories - 0118-01

${ }^{2}$ Merck 655

${ }^{3}$ Fermento Fleishemann (Fermento de Padeiro)
} 
meio assim formulado foi distribuído em tubos pyrex® com tampa rosqueada com volume de $3 \mathrm{ml}$ e autoclavado a $120^{\circ} \mathrm{C}$ durante 15 minutos.

\subsubsection{Preparo do meio sólido para o desenvolvimento de colônias de Flavobacterium}

Infuso de Carne $100 \mathrm{ml}$

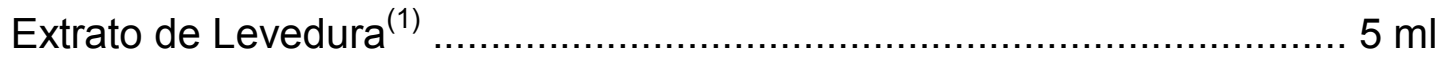

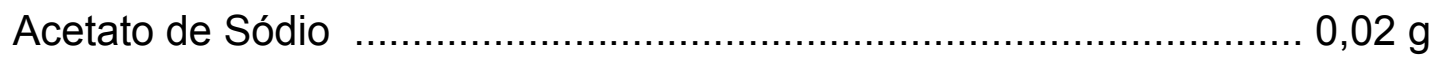

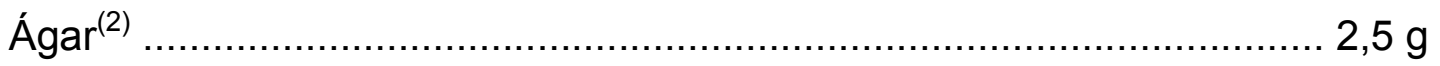

$\mathrm{pH}$ ajustado para 6,8 com $\mathrm{NaOH}$.

O meio sólido assim formulado foi autoclavado a $120^{\circ} \mathrm{C}$ durante 15 minutos num volume de 100 ml e logo após distribuído em placas de Petri de 60 mm de diâmetro, esterilizadas para posterior semeadura.

\subsubsection{Preparo da água peptonada para diluições do material coletado e Provas Bioquímicas}

Água Destilada ............................................................... $100 \mathrm{ml}$

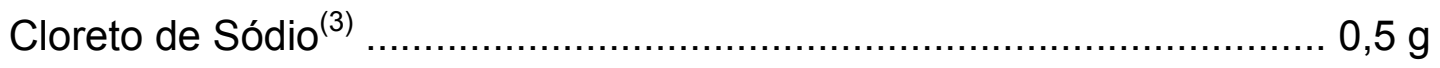

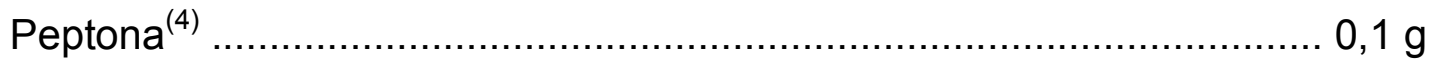

A água peptonada assim formulada foi distribuída em tubo de vidro pyrex® com tampa rosqueada, com volume de $3 \mathrm{ml}$ e autoclavado a $120^{\circ} \mathrm{C}$ durante 15 minutos.

\footnotetext{
${ }^{1}$ Fermento Fleishemann (Fermento de Padeiro)

${ }^{2}$ Bacto Agar - Difco Laboratories - 0140-01

${ }^{3}$ Merck 655

${ }^{4}$ Bacto Peptone Difco Laboratories - 0118-01
} 


\subsubsection{Preparo do meio para a prova da DNase}

DNase test agar ${ }^{(1)}$ $4,2 \mathrm{~g}$

Água destilada $100 \mathrm{ml}$

O meio foi autoclavado a $120^{\circ} \mathrm{C}$ durante 15 minutos e logo após distribuído em placas de Petri de $60 \mathrm{~mm}$ de diâmetro, esterilizadas para posterior semeadura.

\subsubsection{Preparo do meio para a prova da Hidrólise do Amido}

Amido de Milho $1,0 \mathrm{~g}$

Água destilada $100 \mathrm{ml}$

Da solução obtida, tomou-se $0,3 \mathrm{ml}$ e adicionou-se ao meio sólido para o desenvolvimento de Flavobacterium sp.

O meio assim elaborado foi autoclavado e distribuído em placas de Petri de $50 \mathrm{~mm}$ de diâmetro.

\subsubsection{Preparo do meio para a prova da Hidrólise da Gelatina}

Gelatina $^{(2)}$ $15 \mathrm{~g}$

Água destilada $100 \mathrm{ml}$

O meio assim preparado foi distribuído em tubos pyrex® com tampa rosqueada e esterilizado através de tindalização por três dias consecutivos.

\footnotetext{
${ }^{1}$ Bacto Dnase Test Agar - Difco Laboratories - 0632-01

${ }^{2}$ Bacto Gelatin - Difco Laboratories - 0143-01
} 


\subsubsection{Provas Bioquímicas}

As provas bioquímicas foram realizadas utilizando-se o kit *Laborclin para Enterobactérias.

\subsubsection{Outras Provas Bioquímicas}

\subsubsection{Presença de Pigmento de Flexirrubina}

Meio sólido cuja formulação está descrita em 3.3.4, adicionando-se, após o desenvolvimento das colônias, solução de $\mathrm{KOH}$ a 20\% (Bernardet et al., 2002).

\subsubsection{Prova da Absorção do Vermelho Congo}

Meio sólido, cuja formulação está descrita em 3.3.4, adicionando-se, após o desenvolvimento das colônias, solução aquosa de vermelho congo a 1\% (Bernardet et al., 2002).

\subsubsection{Hidrólise da Caseína}

Meio sólido descrito em 3.3.4 ao qual adiciona-se 10\% de leite desnatado, esterilizado por tindalização durante três dias consecutivos.

* Laborclin Produtos para Laboratórios Ltda. Lote 10425075 


\subsubsection{Redução do Nitrato}

Água peptonada formulada como descrito no item 3.3.5 à qual adiciona-se uma solução de nitrato de potássio a 0,1\% (Bier, 1984).

\subsubsection{Técnicas de Coloração}

Coloração pelo Azul de Metileno a 0,5 \% (Bier, 1984).

Coloração de Gram (Bier, 1984).

\subsubsection{Observação da Motilidade}

Uma gota da cultura em meio líquido foi colocada em lâmina de microscopia, seguida de lamínula e uma gota de óleo de imersão, e observada em microscópio óptico comum (aumento de 1000X) para visualizar a motilidade característica de Flavobacterium sp.

\subsection{Processamento Bacteriológico das amostras}

\subsubsection{Semeadura}

Após incubação das amostras por um período de 48 horas em estufa bacteriológica ajustada a $25^{\circ} \mathrm{C}$, retirou-se uma alíquota do caldo através de alça de platina, realizando-se esfregaço em lâmina de microscopia e corada pelo azul de metileno e método de Gram, para a observação microscópica da morfologia dos microorganismos. 
Outra alíquota foi semeada em meio sólido de cultura e incubada a $25^{\circ} \mathrm{C}$ em estufa bacteriológica, por um período de 48 horas, para o desenvolvimento de colônias características de Flavobacterium sp.

Após esse período, as placas foram examinadas em microscópio óptico comum, com aumento de 40 X para a evidenciação das formas rizóides das bordas das colônias, sendo também observada a coloração cinza-amarelada das colônias.

Colônias cujas características sugeriam ser de Flavobacterium $\mathrm{sp}$. foram repicadas em meio líquido e incubadas nas mesmas condições anteriores (item 3.4.1). Amostras que apresentavam contaminação por bastonetes gram negativos foram diluídas através de diluições seriadas na razão 2 em água peptonada e semeadas em meio sólido.

Uma vez obtidas as culturas puras, precedeu-se à caracterização das estirpes isoladas através da citobacterioscopia, características culturais em meio líquido e sólido de cultura, motilidade e provas bioquímicas. 


\section{RESULTADOS}

\subsection{Isolamento de Cepas de Flavobacterium sp. dos peixes}

A aplicação dos recursos descritos no capítulo "Material e Métodos" possibilitou-nos isolar, dos peixes clinicamente diagnosticados como acometidos de columnariose, quatro cepas de microrganismos, assim por nós denominados: K2 para a espécie Brycon orbignyanus (Piracanjuba), K3 para a espécie Piaractus mesopotamicus (Pacu), K4 para a espécie Colossoma macropomum (Tambaqui) e K5 para a espécie Hypostomus plecostomus (Cascudo), que, pela morfologia de suas colônias, aspectos culturais e bioquímicos, puderam ser caracterizadas como pertencentes ao gênero Flavobacterium.

Os esfregaços em lâmina de microscopia corados pelo azul de metileno e método de Gram (Figuras 3 e 4) evidenciaram a presença de bacilos finos agrupados corados em azul e gram negativos. 


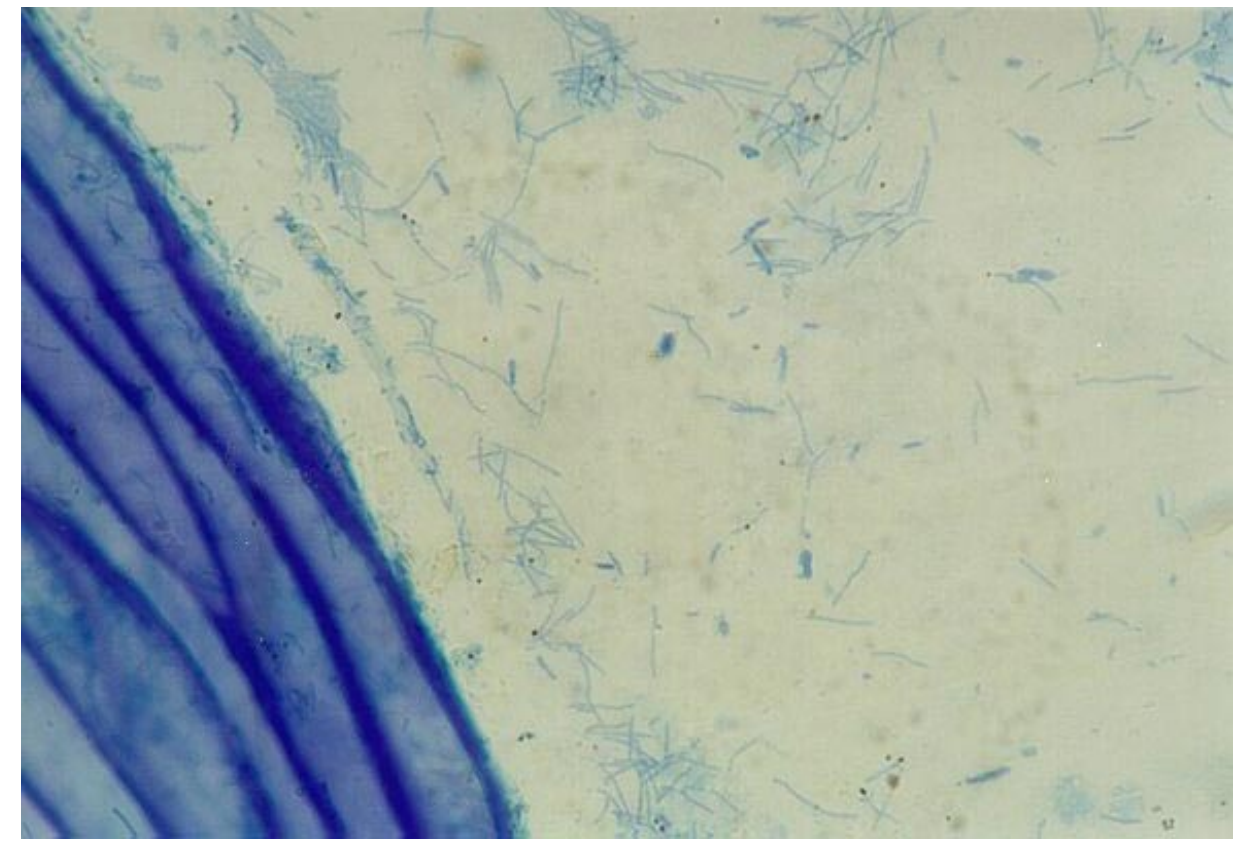

Figura 3. Esfregaço de raspado das áreas lesadas, coradas pelo azul de metileno a $0,5 \%$ (aumento de $1000 \mathrm{X}$ ).

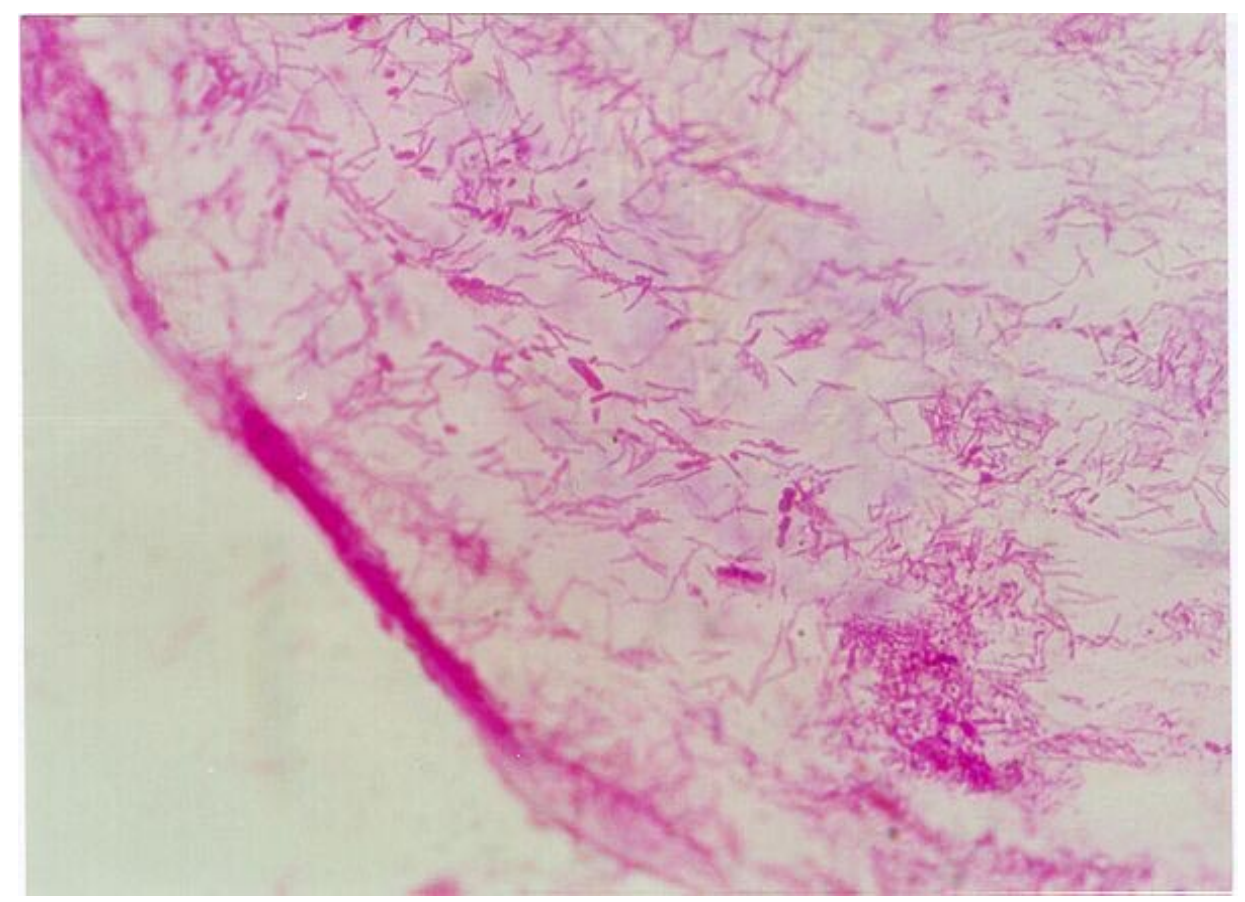

Figura 4. Esfregaço de raspado das áreas lesadas, coradas pelo método de Gram (aumento de 1000 X). 
As culturas em meio líquido apresentaram formações em colunas, (Figura 5) e a observação microscópica em gota pendente exibiu motilidade por deslizamento (Figura 6).

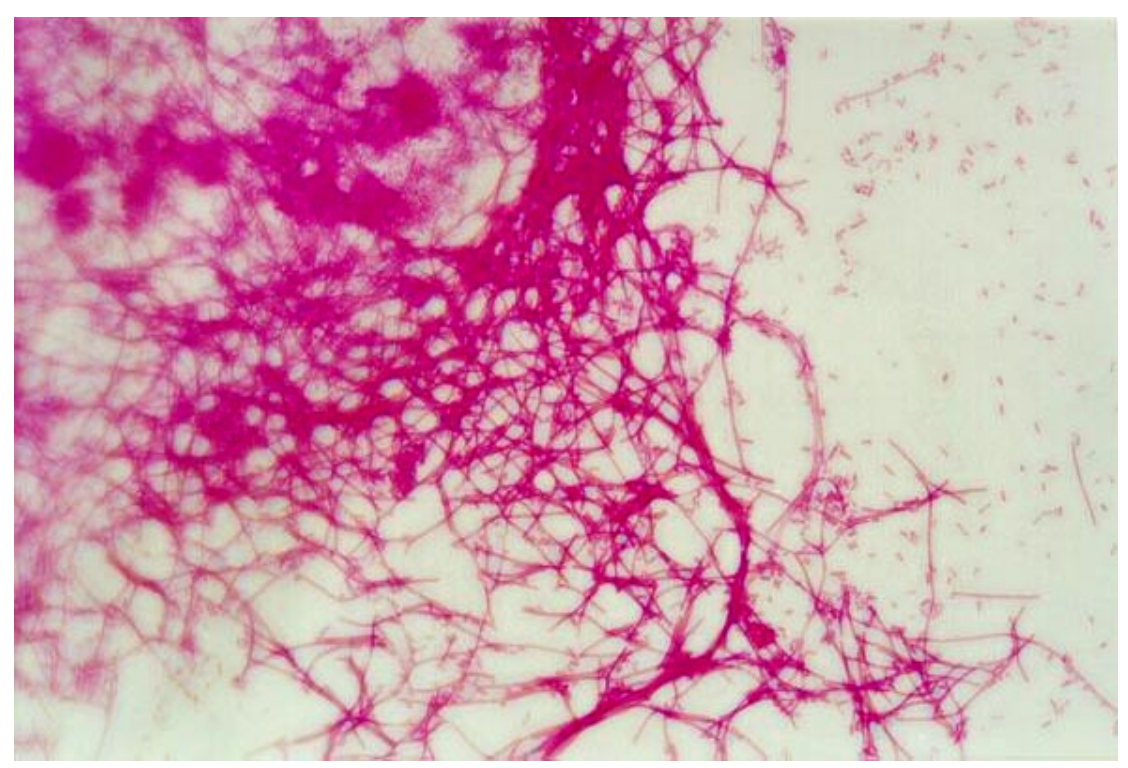

Figura 5. Esfregaço da cultura em meio líquido corado pelo método de Gram (aumento de $1000 \mathrm{X}$ ).

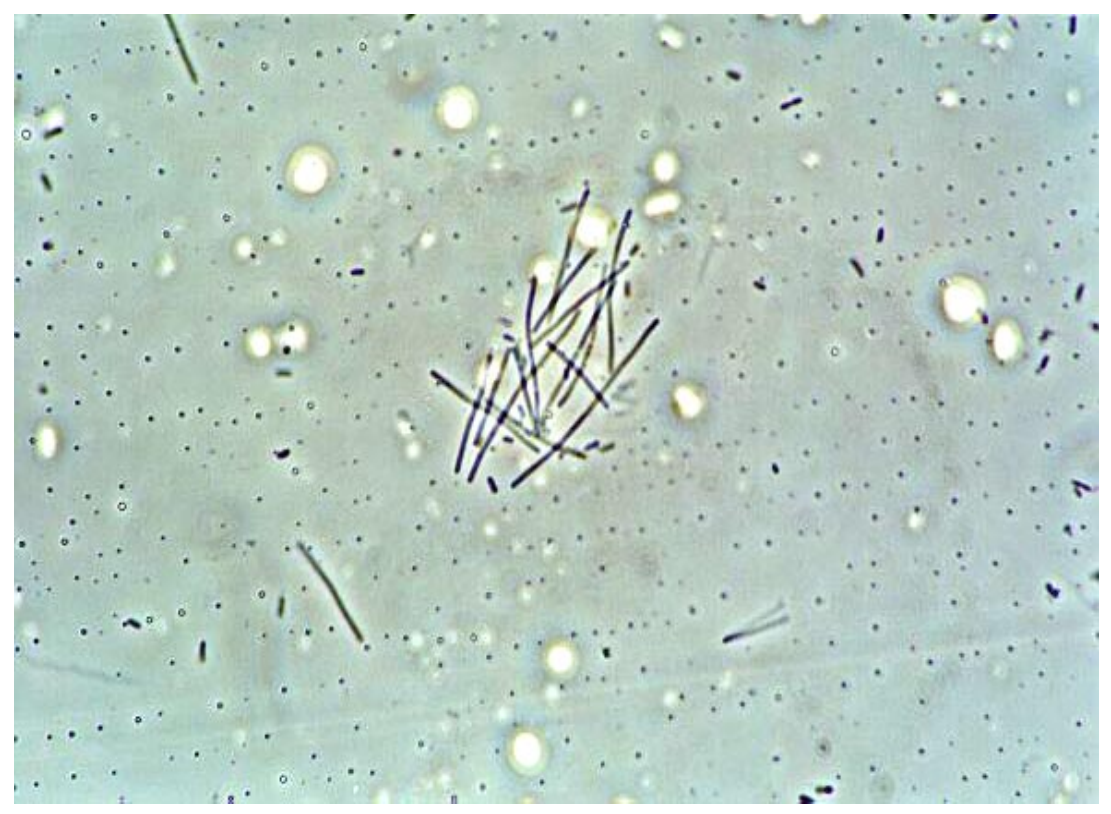

Figura 6. Gota pendente da cultura em meio líquido (aumento de $1000 \mathrm{X})$. 
As colônias desenvolvidas em meio sólido apresentaram morfologia ligeiramente convexa, bordas irregulares em forma de raiz e coloração cinza-amarelada (Figuras 7, 8, 9 e 10), características essas, de colônias do gênero Flavobacterium.

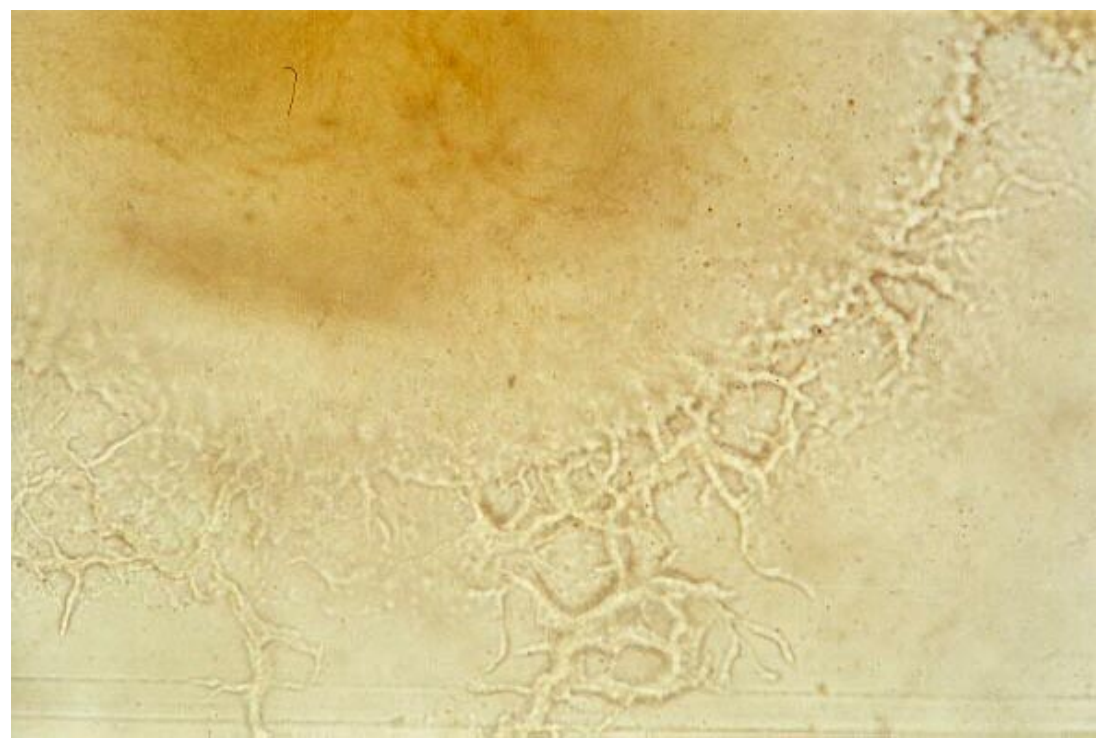

Figura 7. Colônia isolada da espécie Piracanjuba - Brycon orbignyanus (Amostra K2) observada ao aumento de $45 \mathrm{X}$.

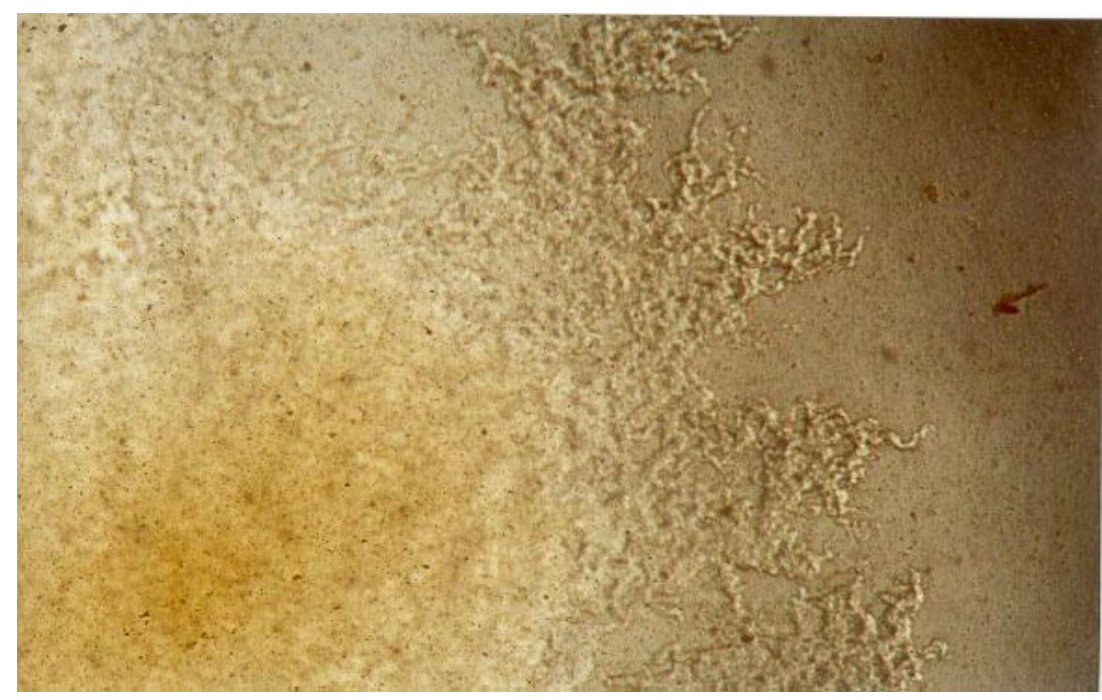

Figura 8. Colônia isolada da espécie Pacu - Piaractus mesopotamicus (Amostra K3) observada ao aumento de 45X. 


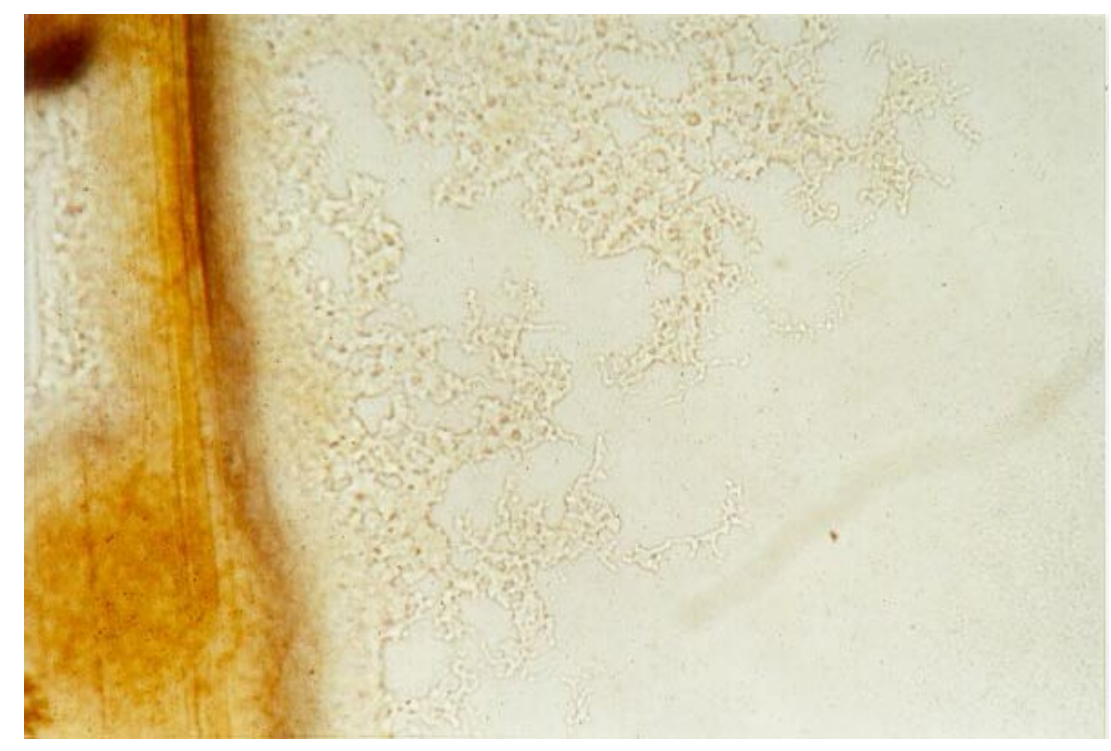

Figura 9. Colônia isolada da espécie Cascudo - Hypostomus plecostomus (Amostra K5) observada ao aumento de 45X.

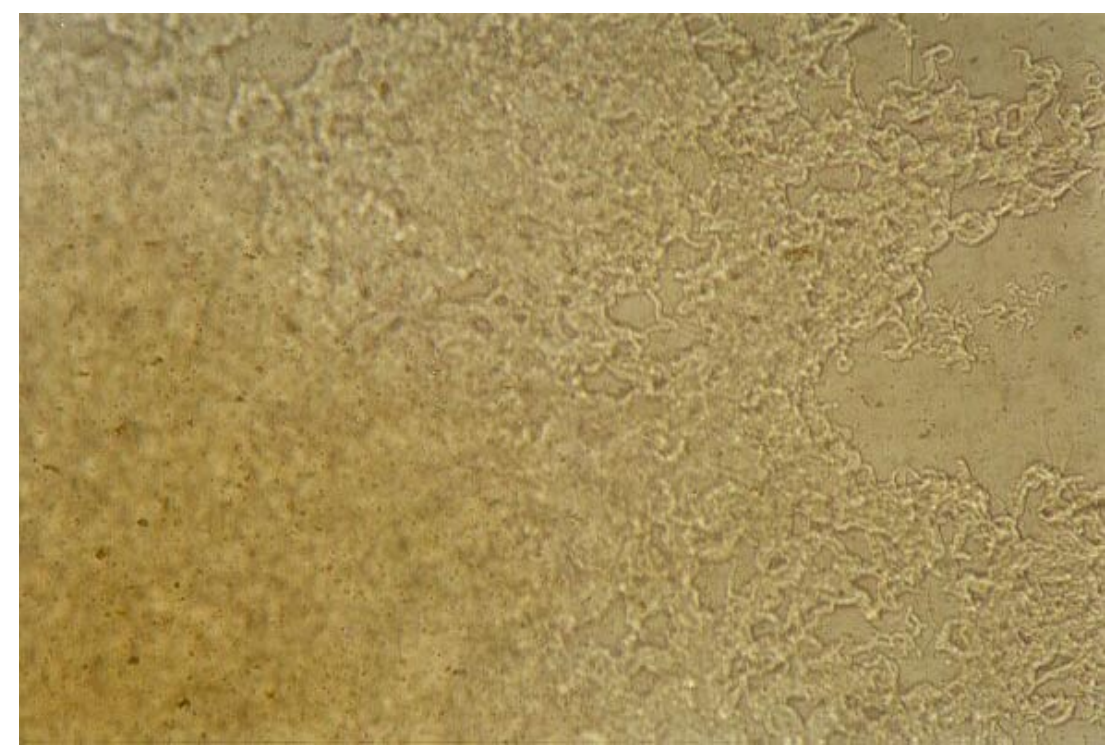

Figura 10. Colônia isolada da espécie Tambaqui - Colossoma macropomum (Amostra K4) observada ao aumento de 45X. 
As características bioquímicas das quatro estirpes isoladas estão expressas na tabela abaixo.

Tabela 1. Características Bioquímicas de Cepas de Flavobacterium isoladas de Peixes Tropicais

Piracanjuba (K2) $\quad$ Pacu (K3) $\quad$ Tambaqui (K4) $\quad$ Cascudo (K5)

Desaminação do L Triptofano

Fermentação da Glicose

Rhamnose

Citrato

Hidrólise da Uréia

Redução de Nitrato

Vermelho Congo

Catalase

Ácido Sulfídrico

$\left(\mathrm{H}_{2} \mathrm{~S}\right)$

Indol

Descarboxilação da

Lisina

Descarboxilação da

Ornitina

Gás a partir da

Glicose

Flexirrubina

Gelatina

Amido

Caseína

DNA

$+$
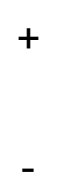

$+$

$+$

$+$

$+$

$+$

$-$

$+$

$+$

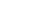

$+$

-
+
+
-
+
+
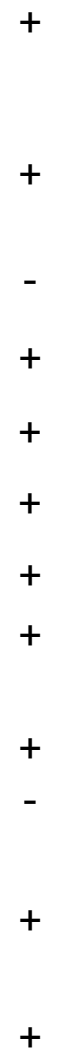

$+$

$+$

$+$

$+$

$+$

$+$

$+$

$+$

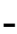

$+$

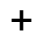

$\begin{array}{llr}- & - & - \\ + & + & + \\ + & + & + \\ - & - & + \\ + & + & + \\ + & + & \end{array}$

+ = Reação Positiva/Degradação de Substrato

- = Reação Negativa/Não Degradação de Substrato 


\section{DISCUSSÃO}

A columnariose é um grave problema de sanidade em peixes tropicais, pois diminui a produção em decorrência da rápida mortalidade de alevinos, ocasionando perda total dos cardumes (Ceccarelli et al., 1990).

A inexistência de trabalhos a respeito, na literatura brasileira, torna o estudo dessa bacteriose dificultoso, principalmente no que diz respeito ao isolamento do agente em meios artificiais de cultura.

Assim, vários autores propuseram a formulação de alguns meios de cultura, tanto sólidos como líquidos, com os quais obtiveram o isolamento de Flavobacterium columnare (Ordal \& Rucker, 1944; Anacker \& Ordal, 1955; Carlson \& Pacha, 1968; Shieh, 1980). Contudo, um dos principais problemas enfrentados pelos pesquisadores com relação à bactéria Flavobacterium columnare é a obtenção de culturas puras desta bactéria (Bernardet, 1989).

$\mathrm{O}$ isolamento de Flavobacterium columnare em meios de culturas artificiais é muito difícil, devido ao post-mortem dos peixes ou ao crescimento exacerbado de bactérias do meio aquático. Já quando são cultivadas de lesões externas dos peixes, o seu desenvolvimento pode ser inibido por bactérias de crescimento mais rápido (Kinnunen et al., 1997). 
Neste experimento, essa condição também foi observada através do desenvolvimento de bastonetes gram negativos em grande quantidade.

Aeromonas spp, Pseudomonas spp e Shewanella putrefaciens estão freqüentemente presentes na pele, brânquias e nadadeiras de peixes saudáveis ou doentes, interferindo no isolamento de Flavobacterium columnare (Decostere et al., 1998).

O isolamento do microorganismo nos meios específicos preconizados na literatura não ocorreu, fato este que nos levou a introduzir modificações no meio de cultura preconizado por Carlson \& Pacha (1968) como descrito no capítulo "Material e Métodos", item 3.3. Este fato difere de relatos de Holmes et al., (1992), que afirmam que as flavobactérias são facilmente isoladas em meios de cultura simples. Outro ponto em que divergimos do pesquisador acima referido é com relação aos nutrientes que compõem os meios de cultura, pois segundo ele, em meio contendo extrato de carne e peptona as flavobactérias não se desenvolvem bem e, em nosso trabalho, utilizamos esses substratos e obtivemos um ótimo crescimento de colônias de Flavobacterium columnare.

Há informações muito escassas sobre a ocorrência, patogenicidade e o isolamento em cultura pura de Flavobacterium columnare de peixes tropicais (Decostere et al., 1998). Neste estudo, a maioria da bibliografia consultada a respeito da columnariose refere-se a espécies de peixes de águas frias e temperadas (Bootsma \& Clerx, 1976; Fish \& Rucker, 1945; Holt et al., 1975). 
$\mathrm{Na}$ tentativa de obtenção de colônias características de Flavobacterium, desenvolvemos um meio de cultura a partir de músculo e escama de tilápia (Oreochromis niloticus), uma vez que o microorganismo em questão é encontrado normalmente nesses tecidos, provavelmente retirando fatores nutricionais importantes para seu metabolismo. Outro motivo é que Carson et al. (1993), realizando a histopatologia das lesões de pele de peixes infectados por Flavobacterium columnare observaram massas filamentosas de bactérias gram negativas nas escamas, pele, musculatura e no edema do tecido conectivo, concluindo que esses tecidos são bons substratos para o desenvolvimento da bactéria.

A dificuldade de isolamento de Flavobacterium columnare foi descrita por Decostere et al. (1998) que obtiveram culturas puras do microorganismo somente após a adição de tobramicina, na concentração de $1 \mu \mathrm{g} / \mathrm{l}$ no meio de cultura proposto por Shieh (1980).

Na formulação do meio de cultura por nós modificado, não optamos em adicionar tobramicina para eliminar bactérias contaminantes, pelo fato de que, se assim o fizéssemos, poderíamos estar induzindo o aparecimento de formas $L$ de bactérias (Davis et al., 1973).

Assim, realizamos diluições das culturas com contaminantes na razão 2 em água peptonada e posterior plaqueamento em meio sólido.

Desta maneira, foram obtidas colônias puras de Flavobacterium que passaram a ser estudadas em suas características morfo-fisiológicas e bioquímicas. 
A identificação das quatro cepas isoladas foi realizada como descrito por Decostere et al. (1997), com base na morfologia das colônias em meio de cultura sólido, morfologia e características bioquímicas do microrganismo.

As quatro cepas por nós isoladas, apresentaram células longas, flexíveis, delgadas em forma de bacilos e gram negativas, com crescimento em aerobiose e temperatura ótima em torno de $25{ }^{\circ} \mathrm{C}$, características essas concordes com as descritas por Bernardet \& Grimont (1989), Reichenbach (1989) e Shamsudin \& Plumb (1996).

Também exibiram motilidade na forma de deslizamento ao exame em gota pendente, o que está de acordo com a descrição de vários autores, entre eles a de Garnjobst (1945) e Shamsudin \& Plumb (1996).

As quatro cepas isoladas desenvolveram no meio sólido colônias cinza-amareladas, o que também é concorde com o observado por Shamsudin \& Plumb (1996).

As colônias assim desenvolvidas apresentaram bordas planas, irregulares, em forma de raiz (rizóides) (Figuras 7, 8, 9 e 10), o que concorda com o demonstrado por Bernardet (1989) e Decostere et al. (1998). Esses mesmos trabalhos citam a característica das colônias de aderirem fortemente à superfície do ágar, o que contraria nossas observações, uma vez que as colônias das cepas por nós isoladas não aderiram fortemente ao agar.

Em relação ao meio líquido de cultura, o desenvolvimento das cepas isoladas, formaram um anel característico na região intermediária do 
líquido, consonante com a descrição de Decostere et al. (1998) ao isolar Flavobacterium de peixes tropicais de aquário.

As colônias formadas no meio sólido de cultura apresentaram uma propriedade organoléptica (odor) semelhante ao cheiro de fruta, fato este também descrito por vários autores (Bernardet, 1989; Decostere et al., 1998; Griffin, 1992; Shamsudim \& Plumb, 1996) ao isolarem Flavobacterium columnare.

Quanto ao comportamento bioquímico das cepas isoladas, em relação à utilização de substratos e detecção de enzimas produzidas, conforme demonstrado na tabela 1 do capítulo "Resultados", verificamos que, embora as quatro cepas tenham sido isoladas de diferentes espécies de peixes, as características bioquímicas foram iguais para todas.

Assim, verificou-se que foram positivas para a desaminação do L-Triptofano, fermentação da glicose, utilização do citrato, catalase, produção de ácido sulfídrico $\left(\mathrm{H}_{2} \mathrm{~S}\right)$, descarboxilação da lisina e da ornitina, DNA, produção de flexirrubina, absorção do vermelho congo, hidrólise da gelatina e da caseína.

A hidrólise da gelatina e da caseína tem sido mencionada como uma das características de Flavobacterium columnare (Bernardet, 1989). Muitas bactérias, incluindo a Falvobacterium columnare, produzem enzimas que degradam uma variedade de macromoléculas, dentre elas a gelatina e a caseína, provocando o clareamento no meio onde ocorreu crescimento bacteriano (Griffin, 1992). As quatro cepas por nós isoladas degradaram a gelatina e a caseína do meio de cultura. 
Em relação à absorção do vermelho congo, as quatro cepas isoladas foram positivas. A positividade dessa prova é citada por Bernardet (1989), Griffin (1992) e Decostere et al. (1999a), como característica importante, pois detecta a produção de galactosamina glucan pela Flavobacterium columnare.

Ainda quanto às características bioquímicas das cepas isoladas, foram negativas a produção de indol, a degradação da rhamnose e a formação de gás a partir da glicose.

Deste modo, caracterizamos as quatro cepas isoladas como sendo do gênero Flavobacterium, por demonstrarem comportamento idêntico em todas as provas às quais foram submetidas. A positividade à absorção do vermelho congo, a presença de flexirrubina, a motilidade por deslizamento e a morfologia das colônias (rizóides) nos fazem acreditar com alta confiabilidade tratarem-se de Flavobacterium columnare.

A partir dos dados obtidos, tornam-se necessários em nosso meio, estudos no sentido de procurar esclarecer a participação desses microrganismos nos quadros nozológicos de peixes tropicais de criação, quanto à columnariose.

Numa seqüência lógica, o próximo passo seria verificar, através de inquérito epidemiológico realizado em várias regiões do País, a extensão do problema. 


\section{CONCLUSÕES}

A conduta laboratorial descrita em "Material e Métodos" possibilitou-nos a obtenção de resultados que, discutidos a analisados, permitem-nos concluir que:

1 - Das lesões dos peixes acometidos de columnariose, isolamos microrganismos que apresentaram comportamento morfofisiológico e bioquímico característicos do gênero Flavobacterium, posteriormente identificados como da espécie columnare.

2 - O meio de cultura por nós proposto, utilizando como fonte protéica escama e músculo esquelético de tilápia (Oreochromis niloticus), facilita o isolamento de Flavobacterium oriundos de peixes tropicais de criação.

3 - Parece-nos ser esta a primeira vez, no Brasil, que microrganismos do gênero Flavobacterium e da espécie columnare são isolados de casos de columnariose nas espécies de peixes tropicais como piracanjuba (Brycon orbignyanus), pacu (Piaractus mesopotamicus), tambaqui (Colossoma macropomum) e cascudo (Hypostomus plecostomus). 


\section{REFERÊNCIAS BIBLIOGRÁFICAS}

AMEND, D. F. Myxobacterial infections of salmonids: prevention and treatment. Amer. Fish. Soc., p. 258-265, 1970.

ANACKER, R. L.; ORDAL, E. J. Study of a bacteriophage infecting the myxobacterium Chondrococcus columnaris. J. Bacteriol., v. 70, p. 738-741, 1955.

ANDERSON, J. L. W.; CONROY, D. A. The pathogenic myxobacteria with special reference to fish diseases. J. Appl. Bacteriol., v. 32, p. 30-39, 1969.

ARANISHI, F. High sensirivity of skin cathepsins $L$ and $B$ of European eel (Anguilla anguilla) to thermal stress. Aquaculture, v. 182, p. 209-213, 2000.

AUSTIN, B.; AUSTIN, D. A. Bacterial fish pathogens: disease in farmed and wild fish. Chichester: Ellis Horwood, 1989. 364 p.

AVTALION, R. R.; WOJDANI, A.; MALIK, Z.; SHAHRABANI, R.;

DUCZYMINER, M. Influences of environmental temperature on the immune response in fish. Microbiol. Immunol. Berlin: Springer-Verlag, 1973. $211 \mathrm{p}$.

BARJA, J. L.; ESTEVEZ-TORANZO, A. Enfermedades bacterianas de peces. In: PELLITERO, A. P.; BARJA, J. L.; BLANCH, A.; ESTEVEZTORANZO, A.; GIORGETTI, G.; TORROELLA, J. J. Patologia en

Acuicultura. Madrid: J. Espinosa de los Monteros e U. Labata, 1988. p. 475-521.

BERMÚDEZ, D. Preliminary experiences in the control of fish diseases in warm water aquaculture operations in Venezuela. J. Fish. Dis., v. 3, p. 355$357,1980$.

BERNARDET, J. F.; GRIMONT, P. A. D. Deoxyribonucleic acid relatedness and phenotypic characterization of Flexibacter columnaris sp. nov., nom. rev., Flexibacter psychrophilus sp. nov., nom. re., and Flexibacter maritimus Wakabayashi, Hikida and Masumura 1986. Int. J. Syst. Bacteriology, v. 39, p. 346-354, 1989. 
BERNARDET, J. F. Flexibacter columnaris: first description in France and comparison with bacterial strains from other origins. Diseases of Aquatic Organisms, v. 6, p. 37-44, 1989.

BERNARDET, J. F.; SEGERS, P.; VANCANNEYT, M. et al. Cutting a Gordian Knot: emended classification and description of the Genus Flavobacterium, emended description of the Family Flavobacteriaceae, and proposal of Flavobacterium hydatis nom. nov. (Basonym, Cytophaga aquatilis Strohl and Tait 1978). Int. J. Syst. Bacteriol., p. 128-148, Jan. 1996.

BERNARDET, J. F.; NAKAGAWA, Y.; HOLMES, B. Proposed minimal standards for describing new taxa of the the family Flavobacteriaceae and emended description of the family. Int. J. Syst. Evol. Micr., v. 52, 18 Jan. 2002. Disponível em: <http://dx.doi.org/10.1099/ijs.0.02136-0>. Acesso 24 abril 2002.

BERTOLINI, J. M.; ROHOVEC, J. S. Electrophoretic detection of proteases from different Flexibacter columnaris strains and assessment of their variability. Diseases Aquatic Organisms, v. 12, p. 121-128, 1992.

BIER, O. Bacteriologia e Imunologia. 18.ed. São Paulo: Melhoramentos, 1977. $991 \mathrm{p}$.

BOOTSMA, R.; CLERX, J. P. M. Columnaris disease of cultured carp (Cyprinus carpio); characterization of the causative agent. Aquaculture, v. 7, p. 371-384, 1976.

BORG. A. F. Studies on myxobacteria associated with diseases of salmonid fishes. J. Wildlife Diseases, v. 8, p. 1-85, 1948.

BRAGG, R. R. Health status of salmonids in river systems in Natal. III Isolation and Identification of bacteria. Onderstepoort J. Vet. Res., v. 58, p. 67-70, 1991.

BULLOCK, G. L. The bacteriology of brook trout with tail rot. Progres. Fish Culturist, p. 19-22, Jan., 1968.

BULLOCK, G. L. et al. A schematic outline for the presumptive identification of bacterial diseases of fish. Progres. Fish Culturist, p. 147-151, Oct, 1971.

CARLSON, R. V.; PACHA, R. E. Procedure for the isolation and enumeration of myxobacteria from aquatic habitats. Appl. Microbiol., v. 16, p. 795-796, May, 1968.

CARSON, J.; SCHMIDTKE, L. M.; MUNDAY, B. L. Cytophaga johnsonae: a putative skin pathogen of juvenile farmed barramundi, Lates calcarifer. J.

Fish Dis., v. 16, p. 209-218, 1993. 
CECCARELLI, P. S.; FIGUEIRA, L. B.; FERRAZ DE LIMA, C. L. B., OLIVEIRA, C. Observações sobre a ocorrência de parasitos de peixes no CEPTA/IBAMA entre 1983 a 1990. Boletim Técnico do CEPTA, Pirassununga, v. 3, p. 43-54, 1990.

CHAMMAS, M. Panorama da aquicultura brasileira: a região sul. In: WORKSHOP INTERNACIONAL DE AQUICULTURA, 1., 1997, São Paulo. Anais... São Paulo: Degaspar, 1997. p. 56-61.

CHEN, D.; AINSWORTH, A. J. Glucan administration potentiates immune defences mechanisms of channel catfish. Ictalurus punctatus. J. Fish Dis., v. 15, p. 295-304, 1982.

CHOWDHURY, M. B .R.; WAKABAYASHI, H. Effects of competitive bacteria on the survival and infectivity of Flexibacter columnaris. Fish Pathol., v. 24, p. $9-15,1989$ a.

CHOWDHURY, M. B. R.; WAKABAYASHI, H. A study on the mechanism of the bacterial competitive effects on Flexibacter columnaris infection: effects of the time-lag between the exposures of fish to Flexibacter columnaris and its competitor. Fish Pathol., v. 24, p. 105-110, 1989b.

DAVIS, H. S. A new bacterial disease of fresh water fishes. U.S. Bur. Fish. Bull., v. 28, p. 261-280, 1923.

DAVIS, H. S. Care and diseases of trout. U.S Fish and Wildlife Service, v. 12, 1946, 98p.

DAVIS, H. S. Infectious disease among wild fishes. Amer. Fish Soc., v. 74, p. 21-25, 1947.

DAVIS, H. S. Cytophaga columnaris as a cause of fish epidemics. Amer. Fish Soc., v. 77, p. 102-104, 1949.

DAVIS, B. D.; DULBECCO, R.; EISEN, H. N.; GINSBERG, H. S.; BARRY WOOD, W. Infecções Bacterianas e Micóticas. Microbiologia, São Paulo: EDART-São Paulo Ltda, p. 310-311, 1973.

DECOSTERE, A.; HAESEBROUCK, F.; DEVRIESE, L. A. Shieh medium suplemented with Tobramycin for selective isolation of Flavobacterium columnare (Flexibacter columnaris) from diseased fish. J. Clin. Microbiol., p. 322-324, Jan., 1997.

DECOSTERE, A.; HAESEBROUCK, F.; DEVRIESE, L. A. Characterization of four Flavobacterium columnare (Flexibacter columnaris) strains isolated from tropical fish. Vet. Microbiol., v. 62, p. 35-45, 1998. 
DECOSTERE, A.; HAESEBROUCK, F.; CHARLIER, G.; DUCATELLE, R. The association of Flavobacterium columnare strains of high and low virulence with gill tissue of black mollies (Poecilia sphenops). Vet. Microbiol., v. 67, p. 287-298, 1999a.

DECOSTERE, A.; HAESEBROUCK, F.; TURNBULL, J. F.; CHARLIER, G. Influence of water quality and temperature on adhesion of high and low virulence Flavobacterium columnare strains to isolated gill arches. J. Fish Diseases, v. 22, p. 1-11, 1999b.

DYAR, M. T.; ORDAL, E. J. Electrokinetic studies on bacterial surfaces: the effects of surface active agents on eletrophoretic mobilities of bacteria. J. Bact., v. 51, p. 149-167, 1946.

FARKAS, J.; OLAH, G. Necrosis: a complex disease of carp. Aquaculture, v. 58, p. 17-26, 1986.

FIJAN, F. J. Antibiotic additives for the isolation of Chondrococcus columnaris from fish. Appl. Microbiol., v. 17, p. 333-334, 1968.

FISH, F.F., RUCKER, R. R. Columnaris as a disease of cold water fishes. Amer. Fish Soc., v. 73, p. 32-36, 1945.

FOSCARINI, R. Induction and development of bacterial gill disease in the eel (Anguilla japonica) experimentally infected with Flexibacter columnaris: pathological changes in the gill vascular structure and cardiac performace. Aquaculture, v. 78, p. 1-20, 1989.

FUJIHARA, M. P.; NAKATANI, R. E. Antibody production and immune responses on Rainbow trout and Coho salmon to Chondrococcus columnaris. J. Fish. Res. Board of Canada, v. 28, n. 9, 1971.

GARNJOBST, L. Cytophaga columnaris (Davis) in pure culture: a myxobacterium pathogenic to fish. J. Bacteriol., v. 49, p. 113-128, 1945.

GEORGIADIS, M. P.; GARDNER, I. A.; HEDRICK, R. P. The role of epidemiology in the prevention, diagnosis and control of infectious diseases of fish. Prev. Vet. Med., v. 48, p. 287-302, 2001.

GRIFFIN, B. R. A simple procedure for identification of Cytophaga columnaris. J. Aquat. Anim. Health, v. 4, p. 63-66, 1992.

HANSON, L. A.; GRIZZLE, J. M. Nitrite induced predisposition of channel catfish to bacterial diseases. Progres. Fish Cult., v. 47, p. 98-101, 1985.

HAWKE, J. P. THUNE, R. Systemic isolation and antimicrobial susceptiblity of Cytophaga columnaris from commercially reared channel catfish. J.

Aquatic Anim. Health. v. 4, p. 109-113, 1992. 
HOLMES, B.; OWEN, R. J.; McMEEKIN, T. A. Genus Flavobacterium Bergey, Harrison, Breed, Hammer and Huntoon 1923. In: Bergey's Manual of Systematic Bacteriology. v. 1. Baltimore: Williams and Wilkins, 1992. p. 353-361.

HOLT, R. A.; SANDERS, J. E.; ZINN, J. L.; FRYER, J. L.; PILCHER, K. S. Relation of water temperature to Flexibacter columnaris infection in steelhead trout (Salmo gairdneri), coho (Oncorhynchus kisutch) and chinook (O. tschawytscha) salmon. J. Fish. Res., v. 32, p.1553-1559, 1975.

JENEY, Z.; JENEY, G. Recent achievements in studies on diseases of Common carp (Cyprinus carpio). Aquaculture, v. 129, p. 397-420, 1995.

JENEY, G.; GALEOTTI, M.; VOLPATTI, D. et al. Prevention of stress in rainbow trout (Oncorhynchus mykiss) fed diets containing different doses of glucan. Aquaculture, v. 154, p. 1-15, 1997.

JOOSTE, P. J.; HUGO, C. J. The taxonomy, ecology and cultivation of bacterial genera beolonging to the family Flavobacteriaceae. Intern. J. Food Microbiol., v. 53, p. 81-94, 1999.

KINNUNEN, P. R.; BERNARDET, J. F.; BLOIGU, A. Yellow pigmented filamentous bacteria connected with farmed salmonid fish mortality.

Aquaculture, v. 149, p. 1-14, 1997.

KIMURA, H.; KUSUDA, R. Microbial succession in gliding bacterium infection in red sea ream. Bull. Japanese Soc. Fish., v. 49, p. 1553-1559, 1983.

KOSKI, P., HIRVELA-KOSKI, V., BERNARDET, J. F. Flexibacter columnaris infection in arctic char (Salvelinus alpinus). First isolation in Finland. Fish Pathol., v. 31, p. 66-69, 1993.

LEADBETTER, E. R. Order II: Cytophagales Nomen novum. In: BUCHANAN, R.E., GIBBONS, N.E. (eds). Bergey's Manual of Determinative bacteriology. 8. ed. Baltimore: Williams and Wilkins, 1974. p. 99-127.

LIEWES, E. W.; VAN DAM, R. H.; VOS MAAS, M. G.; BOOTSMA, R. Presence of antigen sensitized leukocytes in carp (Cyprinus carpio) following bath immunization against Flexibacter columnaris. Vet. Immunol. and Immunopathol., v. 3, p. 603-609, 1982.

MARKS, J. E.; LWEIS, D. H.; TREVINO, G. S. Mixed infection in columnaris disease of fish. J. Am. Vet. Assoc., v. 177, p. 811-814, 1980. 
MARTINS, M. L. Doenças Infecciosas e Parasitárias de peixes. Jaboticabal: FUNEP, 1997. 58 p. (Boletim Técnico da UNESP).

McCARTHY, D. M. Columnaris disease. J. Inst. Fish. Mgmt., v. 6, n. 2, p. 44-47, 1983.

MESQUITA, E. F. M. Cultivo consorciado de peixes na república popular da China. Rev. de Pesca e Pescado. v. 1, n. 1, p. 9-17, 1996.

NEWTON, J. C.; WOOD, T. M.; HARTLEY, M. M. Isolation and partial characterization of extracellular proteases produced by isolates of Flavobacterium columnare derived from Channel catfish. J. Aquatic Anim. Health. v. 9, p. 75-85, 1997.

NIGRELLI, R. F. Causes of disease and dealth of fishes in captivity. Zoologica, v. 28, p. 203-216, 1943.

ORDAL, E. J.; RUCKER, R. R. Pathogenic myxobacteria. Proc. Society Exp. Biology Medicine, v. 56, p. 15-18, 1944.

PACHA, R. E.; ORDAL, E. J. Histopathology of experimental columnaris disease in young salmon. J. Comparat. Pathology, v. 77, p. 419-423, 1967.

PACHA, R. E.; ORDAL, E. J. Myxobacterial diseases of salmonids. Amer. Fish Soc., p. 243-257, 1970.

POST, G. W. Textbook of fish health. New Jersey, 1983. p. 47-49.

REICHENBACH, H. Order Cytophagales Leadbetter 1974. In: STALLEY, J. T.; BRYANT, M. P.; PFENNING, N.; HOLT, J. G. (eds). Bergey's Manual of Systematic Bacteriology. Baltimore: Williams Wilkins Co., 1989. v. 3, p. 2011-2013.

RUCKER, R. R.; JONHSON, H. E.; KAYDAS, G, M. An Interim Report on Gill Disease. Progres. Fish Cult., p. 10-14, Jan., 1952.

RUCKER, R. R.; GUSTAFSON, P. V. et al. An epizootic among rainbow trout. Progres. Fish Cult., v. 15, p. 179-181, 1953.

RUCKER, R. R.; ORDAL, E. J. Infectius diseases of pacific salmon. Amer. Fish Soc., v. 83, p. 297-312, 1954.

SCHRECKENBERGER, P. C. Emended classification and description of the family Flavobacteriaceae and the Genus Sphingobacterium. Clin. Microbiol. News, v. 20, n. 14, p. 115-124, 1998. 
SHAMSUDIN, M. N.; PLUMB, J. A. Morphological, biochemical and physiological characterization of Flexibacter columnaris isolates from four species of fish. J. Aquatic Anim. Health, v. 8, p. 335-339, 1996.

SHIEH, H. S. Studies on the nutrition of a fish pathogen, Flexibacter columnaris. Microbios Lett., v. 13, p. 129-133, 1980.

SOLTANI, M.; MUNDAY, B. L.; BURKE, C. M. The relative susceptibility of fish to infections by Flexibacter columnaris and Flexibacter maritimus.

Aquaculture, v. 140, p. 259-264, 1996.

SONG, Y. L.; FRYER, J. L.; ROHOVEC, J. S. Comparison of six media for the cultivation of Flexibacter columnaris. Fish Pathol., v. 23, p. 91-94, 1988.

STANIER, R. Y. The Cytophaga group: a contribuition to the biology of myxobacteria. Bacteriol. Rev., v. 6, p. 143-196, 1942.

TORANZO, A, E.; BARJA, J. L. Virulence of coldwater fish pathogens. Fish Diseases, p. 127-144, 1993.

TORROELLA, J. J. Aspectos generales de patologia infecciosa. In:

PELLITERO, A. P.; BARJA, J. L.; BLANCH, A.; ESTEVEZ-TORANZO, A.; GIORGETTI, G.; TORROELLA, J. J. Patologia en Acuicultura. Madrid: J. Espinosa de los Monteros e U. Labata, 1988. p. 1-35.

TRIYANTO, A. K.; WAKABAYASHI, H. Genotypic diversity of strains of Flavobacterium columnare from diseased fishes. Fish Pathol., v. 34, n. 2, p. 65-71, 1999.

WAKABAYASHI, H.; EGUSA, S. Preliminary experiments on environmental factors influencing the prevalence of columnaris disease. Fish Pathol., v. 7, p. 58-63, 1972.

WAKABAYASHI, $\mathrm{H}$. Effect of environmental conditions on the infectivity of Flexibacter columnaris to fish. J. Fish Diseases, v. 14, p. 279-290, 1991.

WOOD, E. M.; YASUTAKE, W. T. Histopathology of fish (Gill Disease). Progres. Fish Cult., p. 07-13, Jan. 1957.

ZHAO, G.; CHUNG, K. T.; MILOW, K.; WENXIAN, W.; STEVENS, E. S. Antibacterial properties of tannic acid and related compounds against the fish pathogen Cytophaga columnaris. J. Aquatic Anim. Health, v. 9, p. 309-313, 1997. 